\title{
Nitric oxide - the endothelium-derived relaxing factor and its role in endothelial functions
}

\author{
Viktor Bauer and Ružena Sotníková
}

Institute of Experimental Pharmacology and Toxicology, Slovak Academy of Sciences, Bratislava, Slovakia

\begin{abstract}
Vascular endothelium plays a key role in the local regulation of vascular tone and vascular architecture by release of vasodilator and vasoconstrictor substances, as well as factors with pro-coagulant, anticoagulant, fibrinolytic, antibacterial properties, growth factors, chemokines, free radicals, etc. Release of endothelium-derived relaxing factors such as nitric oxide (NO), prostaglandins and endothelium-derived hyperpolarizing factor, as well as vasoconstricting factors such as endothelin, superoxide and thromboxanes play an influential role in the maintenance and regulation of vascular tone and the corresponding peripheral vascular resistance. Under physiological conditions, the release of anticoagulant and smooth muscle relaxing factors exceeds the release of other substances. The first part of this review presents the functions of the endothelium itself, the nature of the endothelium-derived relaxing factor, its production by $\mathrm{NO}$ synthases, mechanisms of its action via activation of soluble guanylyl cyclase and production of cyclic 3'-5'-guanosine monophosphate. The resulting biological effects include vasodilatation, regulation of vessel wall structure, increased regional blood perfusion, lowering of systemic blood pressure, antithrombosis and antiatherosclerosis effects, which counteract the vascular actions of endogenous vasoconstrictor substances. Impaired endothelial function, either as a consequence of reduced production/release or increased inactivation of endothelium-derived vasodilators, as well as interactions of $\mathrm{NO}$ with angiotensin, reactive oxygen species and oxidized lipoproteins, has detrimental functional consequences and is one of the most important cardiovascular risk factors. Therefore the second part of this review assesses the pathophysiologic impact of the endothelium in examples of cardiovascular pathologies, e.g. endotheliopathies caused by increased angiotensin production, lipid peroxidation, ischemia/reperfusion or diabetes.
\end{abstract}

Key words: Endothelium - Endothelium-derived factors - Angiotensin - Lipid peroxidation - Ischemia/reperfusion - Diabetes — Endotheliopathies

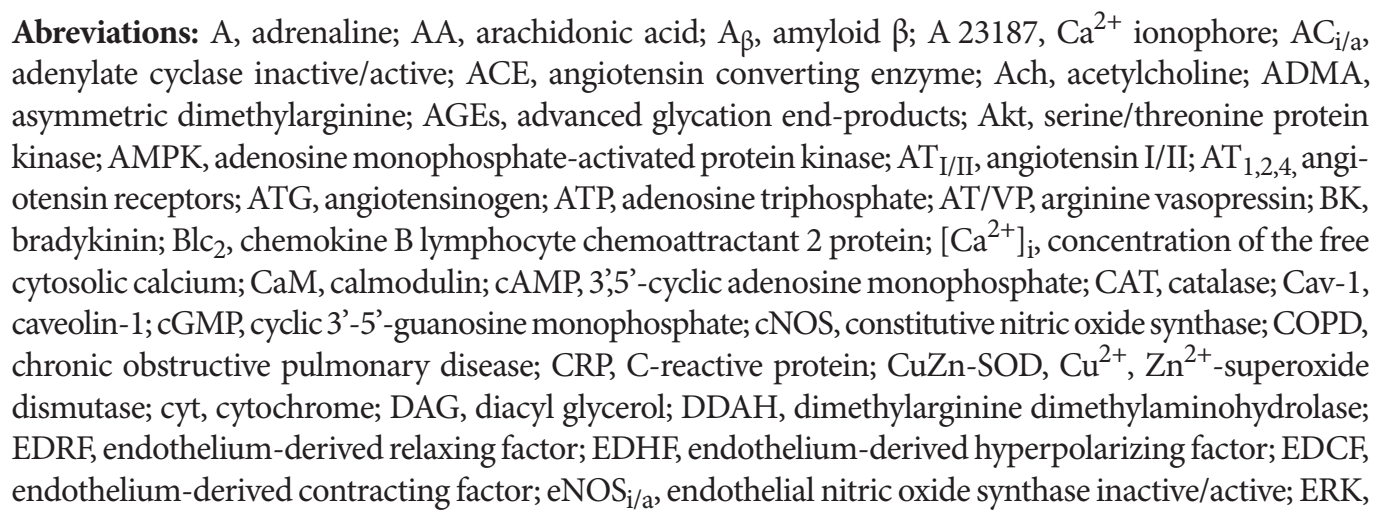

Correspondence to: Viktor Bauer, Institute of Experimental

Pharmacology and Toxicology, Slovak Academy of Sciences,

Dúbravská cesta 9, 84104 Bratislava, Slovakia

E-mail: Viktor.Bauer@savba.sk 
extracellular signal regulated kinase; $\mathrm{ET}$, endothelin; $\mathrm{ET}_{\mathrm{B}, 2}$, endothelin receptors; $\mathrm{FAD} / \mathrm{FMN}$, flavin adenine dinucleotide/flavin mononucleotide; GLUT-4, glucose transporter; GMP, guanosine monophosphate; GPx, glutathione peroxidase; GSNO, nitroso-L-glutathione; GTP, guanosine-5'-triphosphate; HDL, high-density lipoprotein; $\mathrm{H}_{2} \mathrm{O}_{2}$, hydrogen peroxide; $\mathrm{Hi}$, histamine; $\mathrm{H}_{1,2}$, histamine receptors; $\mathrm{HIF}$, hypoxia inducible factor; Hsp90, heat shock protein; 5-HT, serotonin; ICAM-1, intercellular adhesion molecule-1; IDE, insulin-degrading enzyme; IFN- $\gamma$, interferon-gamma; $\mathrm{IL}_{6}$, interleukin 6 ; iNOS, $\mathrm{NOS}_{2}$, inducible nitric oxide synthase; $\mathrm{IP}_{2}$, inositol-4,5-bisphosphate; $\mathrm{IP}_{3}$, inositol-1,4,5-trisphosphate; $\mathrm{I} / \mathrm{R}$, ischemia/reperfusion; IRF-1, interferon regulatory factor 1 ; IRS-1, insulin receptor substrate; $\mathrm{K}_{\mathrm{Ca}}, \mathrm{Ca}^{2+}$-dependent potassium channels; LPO, lipid peroxides; MAPK, mitogen-activated protein kinase; MCP-1, monocyte chemoattractant protein-1; MPT, mitochondrial permeability transition pore; $\mathrm{NA}$, noradrenaline; $\mathrm{NADPH} / \mathrm{NADPH}{ }^{+}$, reduced/oxidized nicotinamide adenine dinucleotide phosphate; NF-kB, nuclear factor kappa B; NF- $\kappa \mathrm{B}$, nuclear factor kappa-light-chain-enhancer of activated B cells; $\mathrm{NO}$, nitric oxide; ${ }^{\circ} \mathrm{NO}$, nitric oxide radical; NOS, NO synthase; $\mathrm{nNOS}$, ncNOS, NOS1, neuronal nitric oxide synthase; $\mathrm{O}_{2}{ }^{--}$, superoxide anion radical; $\mathrm{ONOO}^{\circ-}$, peroxynitrite; oxLDL, oxidized low-density lipoproteins; PhE, phenylephrine; PAF, platelet activating factor; $\mathrm{PDE}_{5}$, phosphodiesterase $\mathrm{E}_{5}$; PDK-1, pyruvate dehydrogenase kinase isozyme 1; pGC, particulate guanylate cyclase; $\mathrm{PGD}_{2}, \mathrm{PGE}_{2}$, 6-keto $\mathrm{PGF}_{1}, \mathrm{PGH}_{2}$, prostaglandins; $\mathrm{PGI}_{2}$, prostacyclin; $\mathrm{PI}$, phosphatidyl inositol; $\mathrm{PI}_{3}-\mathrm{K}_{\mathrm{i} / \mathrm{a}}$, phosphatidylinositol 3-kinase inactive/active; $\mathrm{PK}_{\mathrm{A} / \mathrm{C} / \mathrm{G} / \mathrm{I}}$, protein kinases $\mathrm{A} / \mathrm{C} / \mathrm{G} / \mathrm{I} ; \mathrm{PK}_{\mathrm{B}}, \mathrm{PI}_{3}$-kinase/Akt (active human protein kinase); PLC, phospholipase C; PPAR-a, peroxisome proliferator-activated receptor $\alpha$; RNS, reactive nitrogen species; RSH, glutathione; ROS, reactive oxygen species; ROC/VOC, receptor/voltage operated $\mathrm{Ca}^{2+}$ channels; RSNO, S-nitrosothiols; Ser, Serine; $\mathrm{sGC}_{\mathrm{i} / \mathrm{a}}$, soluble guanylate cyclase inactive/active; $\mathrm{SNO}$ albumin, S-nitroso-albumin; SNO Hb, S-nitrosohemoglobin; SP, substance P; SR, sarcoplasmic reticulum; $\mathrm{TD}_{2}$, type 2 diabetes; $\mathrm{THB}_{4},(6 R)$ 5,6,7,8-tetrahydrobiopterin; Thr, threonine; Tr, thrombin; Trx, thioredoxin; tPA, tissue plasminogen activator; $\mathrm{TNF}_{\alpha}$, tumor necrosis factor $\alpha$; $\mathrm{TxA}_{2}$, thromboxane $\mathrm{A}_{2}$; VEGF, vascular endothelial growth factor; VCAM-1, vascular cell adhesion molecule-1.

\section{Introduction}

The high incidence of cardiovascular diseases has become a worldwide problem. According to statistical data, they are the most frequent cause of death. Atherosclerosis and its complications commonly become seriously symptomatic only when interfering with coronary, cerebral or other tissue circulation. They are considered to be the most important causes of strokes, heart attacks, various heart diseases, including congestive heart failure, and of most cardiovascular diseases accompanying other illnesses, such as diabetes mellitus, rheumatic disease, etc. Moreover, several pathological conditions including diabetes mellitus, chronic inflammations, and hypercholesterolemia, promote disruption of the homeostatic mechanisms of the endothelial protective barrier. These result in an increased adhesiveness of the endothelium to leukocytes, altered permeability of the endothelium, and consequently in enhanced reactivity of the adjacent vascular smooth muscle. The discovery that nitric oxide (NO), an air pollutant, serves as a mediator of biological processes has been one of the most remarkable advances in biomedical research at the end of the last century. Over the past two to three decades, a number of studies have implicated that this simple molecule is involved in various physiological and pathophysiological processes. In this article we provide a comprehensive review on the endothelium derived relaxing factor NO and its role in endothelial function.

\section{The endothelium}

Although already in 1966 Florey suggested that "vascular endothelium is more than a simple layer of cellophane composed of cells", its importance in physiological functions of the cardiovascular system was uncovered only during the last decades. This thin layer of cell line covers the interior surface of blood vessels of the entire circulatory system (about $5000 \mathrm{~m}^{2}$ ), from the heart to the smallest capillary. It comprises about $2 \%$ of the mass of the human body. The endothelium with subendothelium form an interface between circulating blood in the lumen of vessels and the rest of the vessel wall. As a selective barrier between the blood and the surrounding tissues, intact endothelium mechanically separates platelets and their pro-coagulant products from intravascular, subendothelial and tissue coagulation factors, and it also inhibits pro-coagulant proteins (Eisenberg 1991). It controls the passage of materials and the transit of white blood cells into and out of the bloodstream, reduces turbulence of the flow of blood, allows the fluid to be pumped further and participates in fibrinolysis by the production of tissue plasminogen activator (tPA) (Van Hinsbergh 1988). There are also highly differentiated endothelial cells which perform specialized "filtering" functions. Such unique endothelial structures include the renal glomerular and the blood-brain barriers (Cryer 1998). 
The vascular endothelium responds dynamically to different circulating factors, consequently and significantly influences the blood vessel contractile tone and vascular architecture. Endothelial cells produce factors with pro-coagulant, anticoagulant, fibrinolytic, antibacterial properties and generate vasoactive molecules, like platelet-activating factor (PAF), blood clotting factors III, V and VIII, kininogen, tPA, endothelium derived relaxing (EDRF), hyperpolarizing (EDHF) and contracting (EDCF) factors, endothelins (ET), vascular endothelial growth factor (VEGF), eicosanoids (prostaglandins, prostacyclines and thromboxanes; $\mathrm{PGD}_{2}, \mathrm{PGE}_{2}, \mathrm{PGI}_{2}, \mathrm{TxA}_{2}$, $\mathrm{PGH}_{2}$, 6-keto $\mathrm{PGF}_{1}$ ), interleukins (IL), chemokines, nuclear factor kappa-light-chain-enhancer of activated B cells (NF-kB), reactive oxygen species (ROS), reactive nitrogen species (RNS), bradykinin (BK), angiotensin II $\left(\mathrm{AT}_{\mathrm{II}}\right)$, histamine, etc. They play an influential role in maintenance and regulation of vascular smooth muscle tone and peripheral vascular resistance. They ensure tissue homeostasis and the delicate balances in vessel wall proliferation, blood clotting, adherence of blood elements to vessel wall and local inflammation (Lüscher 1988; Vanhoutte 1988; Yanagisawa et al. 1988; Vane et al. 1990; Rubanyi 1991a; Darley-Usmar and Halliwell 1996; Stocker and Keaney 2004). Under physiological conditions, the release of anticoagulant and smooth muscle relaxing factors by the endothelium exceeds the release of other substances (Furchgott and Vanhoutte 1989; Vanhoutte et al. 1991).

The endothelium is the primary target in many pathologies. There are numerous humoral factors which induce endothelial dysfunction. Increased concentration of factors like IL-6, monocyte chemoattractant protein-1 (MCP-1), tumor necrosis factor- $a$ (TNF- $\alpha$ ), C-reactive protein (CRP) or decreased concentration of factors like plasma adiponectin facilitate consequences of endothelial dysfunction. Impaired endothelial function appears to be an important determinant in the relationship between chronic inflammation and cardiovascular deterioration (Cleland et al. 2000; Hingorani et al. 2000; De Jager et al. 2006). Excessive or prolonged increase in permeability of the endothelial monolayer, as e.g. in cases of chronic inflammation, may lead on the one side to tissue edema and on the other side to an increased contractile activity of smooth muscle of the vessel wall. Moreover, it is well established that loss of endothelial cells from the intimal surface predisposes to vascular lesion formation, manifested e.g. in vessel wall stiffening, development of atherosclerotic plaques, etc. (Ross 1993; Pasceri et al. 2000; Booth et al. 2004; McEniery et al. 2004; Duprez et al. 2005).

Scientific upsurge in the last several decades has revealed that deterioration of the endothelium with subsequent damage of smooth muscle reactivity results in generalized increase in vascular tone, platelet aggregation, thrombus formation, etc. (Katušic and Vanhoutte 1986; Rubanyi and Vanhoutte 1986 a,b; Rubanyi 1988; Yanagishawa et al. 1988; Lüscher et al. 1992). It participates and plays a substantial role in the generation of various diseases like atherosclerosis (Ross 1993, 1999;
Heitzer et al. 1996; Besler et al. 2008; Heistad 2008), essential hypertension (Lüscher 1988; Vanhoutte 1992; Taddei et al. 1995; Besler et al. 2008), diabetes mellitus and diabetic vasculopathies (Makimattila et al. 1996; Bakker et al. 2009; Nathanson and Nyström 2009), chronic obstructive pulmonary disease - COPD (Peinado et al. 2008), rheumatoid arthritis (Hansel et al. 2003; Szekanecz and Koch 2008), psoriatic arthritis (Gonzalez-Juanatey et al. 2007), osteoarthritis (Miller et al. 2007), ankylosing spondylitis (Sari et al. 2006), systemic lupus erythematosus (Piper et al. 2007), cancer metastasis (Johansson et al. 2010; Takala et al. 2010), migraine and stroke (Besler et al. 2008; Elliott 2008), anaphylactic and traumatic shock (Menardi et al. 2006; Shi et al. 2007; Nakashidze 2009), systemic inflammatory response syndrome (Neary and Redmond 1999; Hingorani et al. 2000; Menardi et al. 2006), NO-induced vasoplegia in sepsis (Stawicki et al. 2008; Funk et al. 2009) and cardiac surgery (Davies and Hagen 1993; Menardi et al. 2006) as well as in many other cardiovascular (Rubanyi 1988, 1991b; Mugge et al. 1989; Davies and Hagen 1993; Münzel 2008; Chorianopoulos et al. 2009), nervous, gut (Vareniuk et al. 2009; Wittmeyer et al. 2010; Zhang et al. 2010), respiratory (Redington 2006; Peinado et al. 2008), genitourinary (Aversa et al. 2010; Sullivan et al. 2010), inflammatory and immune diseases (Hingorani et al. 2000; Harrison et al. 2006; Ghiadoni et al. 2008), etc.

\section{Endothelium-derived relaxation and the nature of EDRF}

The finding that relaxation of vessels induced by acetylcholine depends on the presence of intact endothelium (Fig. 1)

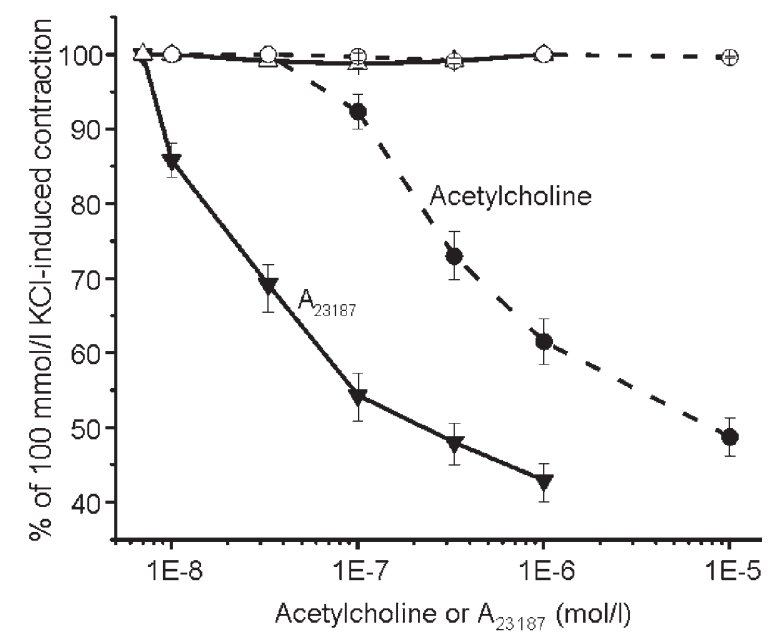

Figure 1. Effects of endothelium removal on acetylcholine and $\mathrm{A}_{23187}$-induced relaxation of potassium chloride $(100 \mathrm{mmol} / \mathrm{l})$ precontracted isolated rat aortic rings. Each value represents mean \pm S.E.M of at least 7 observations. Full symbols are in the presence, open symbols in the absence of endothelium. 
implied the release of EDRF (Furchgott and Zawadski 1980; Zawadski et al. 1980), which exists only for several seconds (Lüscher 1988). It has been found that EDRF is neither an eicosanoid (Lüscher 1988) nor ROS (Gryglewski et al. 1986; Rubanyi and Vanhoutte 1986a).

Murad et al. (1978) found that nitroglycerin exerted vasorelaxation due to release of NO. In the late 1980s, three groups (Ignarro et al. 1987, 1988; Palmer et al. 1987; Furchgott 1988) independently reported that EDRF might be NO. NO was found to be generated by cells that produce EDRF (Noack and Feelisch 1989). Both NO and EDRF possess similar chemical properties, their production is the same and they evoke relaxation by increased production of cyclic 3'-5'-guanosine monophosphate (cGMP) (Ignarro et al. 1987; Furchgott 1988; Ignarro 1990b). With an unpaired electron, $\mathrm{NO}$ is called a radical molecule $\left({ }^{\circ} \mathrm{NO}\right)$, which is highly reactive, having a half-life similar to EDRF (Kanner et al. 1991). After transmitting a signal, it spontaneously decays into nitrite within 2 to 30 seconds. Its bound forms (e.g. nitrosothiols, disulphides or dinitro ferrocysteine) are more stable than $\mathrm{NO}$ itself and might be its intracellular storage forms (Rubanyi et al. 1989; Girard and Potier 1993; Mülsch et al. 1993).

Neuronal and humoral mediators, e.g. acetylcholine (Ach), adrenaline (A), noradrenaline (NA), histamine (Hi), serotonin (5-HT), adenosine triphosphate (ATP), adenosine, substance $\mathrm{P}(\mathrm{SP})$, arginine vasopressin (AT/VP), bradykinin (BK), thrombin (Tr) and $\mathrm{Ca}^{2+}$ - ionophore A 23187 (Furchgott and Zawadski 1980; Zawadski et al. 1980; Vanhoutte and Eber 1991), VEGF (Trouillon et al. 2010), insulin (Kim et al. 2006), angiotensin (Toda et al. 2007), TNF- $a$ (Nakashidze 2009), IL-6 (Andersen and Pedersen 2008), arginase (Bratt et al. 2009), asymmetric dimethylarginine (ADMA) (Cooke 2005), dimethylarginine dimethylaminohydrolase (DDAH) (Achan et al. 2003), etc. acting in their corresponding receptors or cellular structures can affect production and release of NO (Fig. 2).

In endothelial cells, the production or release of $\mathrm{NO}$ is preceded or accompanied by enhanced phosphatidyl inositol (PI) turnover and increase in concentration of the resting free cytosolic calcium $\left(\left[\mathrm{Ca}^{2+}\right]_{\mathrm{i}}\right)$ (Büsse et al. 1988; Stanfield et al. 1990; Vanhoutte and Eber 1991; Adams et al. 1993). Elevation of free $\left[\mathrm{Ca}^{2+}\right]_{i}$ is due to transient release of $\mathrm{Ca}^{2+}$ from intracellular stores and its influx from extracellular space $\mathrm{via} \mathrm{Ca}^{2+}$ channels (Johns et al. 1987; Ryan 1989; Elliot et al. 1992). An increase of free $\left[\mathrm{Ca}^{2+}\right]_{\mathrm{i}}$ is a signal for increased production of NO by endothelium (Wong and Klassen 1992). Its release is oxygen-dependent (DeMey and Vanhoutte 1983; Johns et al. 1989). In addition, the elevated $\mathrm{Ca}^{2+}$ concentration in the vicinity of the endothelial cell plasma membrane activates the $\mathrm{Ca}^{2+}$-dependent potassium channels $\left(\mathrm{K}_{\mathrm{Ca}}\right)$ and evokes membrane hyperpolarization (Lambert et al. 1986; Leuris and Hendersen 1987; Adams et al. 1993) (Fig. 2).

\section{NO synthase}

Palmer et al. (1987, 1988), Moncada et al. (1989) and Ignarro (1990a) reported that NO was formed by an enzyme, called NO synthase (NOS) that transforms L-arginine to L-citrulline in the presence of cofactors such as (6R)-5,6,7,8tetrahydrobiopterin $\left(\mathrm{THB}_{4}\right)$, reduced nicotinamide adenine dinucleotide phosphate (NADPH), and flavin adenine dinucleotide/flavin mononucleotide (FAD/FMN) (Fig. 2).

Structural domain studies of the NOS molecule have identified separate oxygenase and reductase domains (Alderton et al. 2001). The carboxyl-terminal reductase domain is homologous to cytochrome P450 reductase. An aminoterminal oxygenase domain contains a hem prosthetic group, which is linked in the middle of the protein to a calmodulin (CaM)-binding domain.

There are three different isoforms of NOS widely expressed in virtually all cell types, two are constitutive (cNOS) and the third is inducible (iNOS) (Palmer et al. 1987; 1988; Moncada et al. 1989). They share about 50-60\% sequence identity and are divided into two categories with different regulation and activities. The cNOSs are always present in endothelial $\left(\mathrm{NOS}_{3}\right.$, eNOS, ecNOS) and neuronal $\left(\mathrm{NOS}_{1}\right.$, nNOS, ncNOS) cells. The inducible NOS isoform (iNOS, $\mathrm{NOS}_{2}$ ) is normally elusive and is present mainly in the immune and cardiovascular system.

Until the intracellular $\mathrm{Ca}^{2+}$ level increases, eNOS remains inactive. $\mathrm{Ca}^{2+}$ then binds to the calcium-binding protein $\mathrm{CaM}$ and the $\mathrm{Ca}^{2+}-\mathrm{CaM}$ complex binds to and activates eNOS. In response to a rise in endothelial intracellular $\mathrm{Ca}^{2+}$ concentration, eNOS catalyzes the production of NO (Sanders et al. 2000). The increase in the intracellular $\mathrm{Ca}^{2+}$ promotes the dissociation of eNOS from the protein caveolin-1, necessary to its activation (Feron et al. 1996; Gratton et al. 2000). This suggests that caveolae may function as a site of integration of events linking extracellular stimuli and intracellular effectors. The $\mathrm{Ca}^{2+}$ dependent eNOS synthesizes small amounts of $\mathrm{NO}$ until $\mathrm{Ca}^{2+}$-levels decrease. This $\mathrm{Ca}^{2+}$-dependent eNOS provides basal release of NO, which is thought to occur as a result of the fact that the intracellular $\mathrm{Ca}^{2+}$ level in unstimulated endothelial cells is sufficient to activate CaM and eNOS (Loscalzo and Vita 2000). In the healthy vessel, the endothelium serves as the main source of NO production through eNOS activity to maintain vascular tone and regulate platelet aggregation and leukocyte adhesion (Bredt and Snyder 1990) (Fig. 2).

A requirement for catalytic activity of eNOS is dimerization, although the truly active form is a complex of two NOS monomers associated with two CaMs. Binding of $\mathrm{Ca}^{2+}$-CaM appears to act as a "molecular switch" to enable the flow of electrons from the reductase domain, which contains relatively tightly-bound FAD and FMN, to iron protoporphyrin IX (hem) and $\mathrm{THB}_{4}$ in the oxygenase domain. 


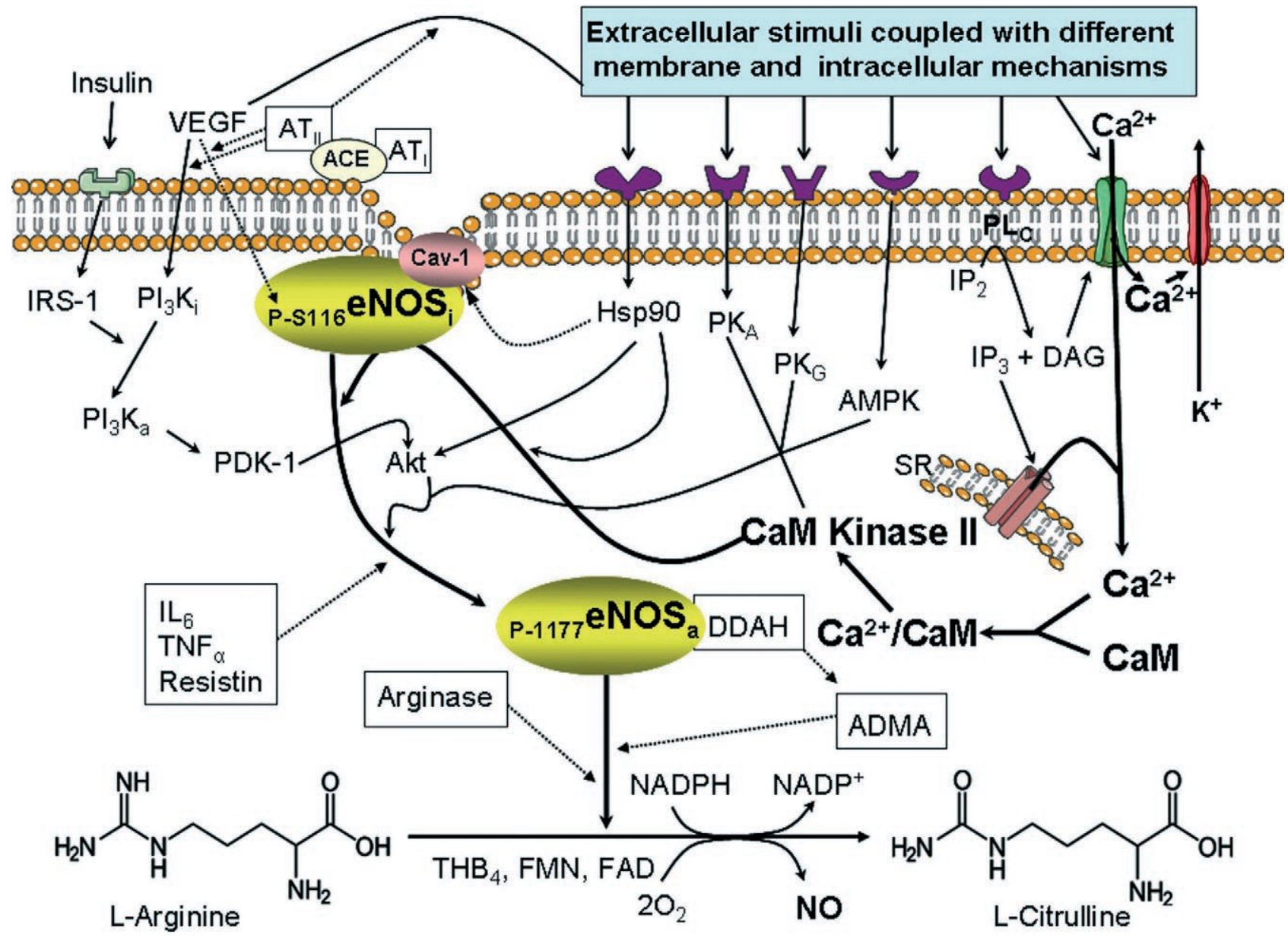

Figure 2. Mechanism of NO synthesis in endothelial cells due to activation of eNOS (eNOS $\mathrm{i}_{\mathrm{i} / \mathrm{a}}$ - endothelial nitric oxide synthase inactive/active) by various stimuli acting on receptors and ion channels coupled by different membrane and intracellular processes (symbolized by angiotensin I/II, IRS-1, insulin receptor substrate; Cav-1, caveolin-1; $\mathrm{PI}_{3}-\mathrm{K}_{\mathrm{i} / \mathrm{a}}$, phosphatidylinositol 3-kinase inactive/active; PDK-1, pyruvate dehydrogenase kinase isozyme 1; Akt, serine/threonine protein kinase; Hsp90, heat shock protein; $\mathrm{PK}_{\mathrm{A} / \mathrm{G}}$, protein kinase A/G; $\mathrm{PL}_{\mathrm{C}}$, phospholipase $\mathrm{C}$; $\mathrm{IP}_{2}$, inositol-4,5-bisphosphate; $\mathrm{IP}_{3}$, inositol-1,4,5-trisphosphate; DAG, diacyl glycerol; AMPK, adenosine monophosphate-activated protein kinase; CaM, calmodulin; DDAH, dimethylarginine dimethylaminohydrolase; ADMA, asymmetric dimethylarginine; $\mathrm{IL}_{6}$, interleukin 6 ; $\mathrm{TNF}_{\alpha}$, tumor necrosis factor $\alpha ; \mathrm{NADPH} / \mathrm{NADPH}^{+}$, reduced/oxidized nicotinamide adenine dinucleotide phosphate; $\mathrm{THB}_{4},(6 R)-5,6,7,8$-tetrahydrobiopterin; FAD/FMN, flavin adenine dinucleotide/flavin mononucleotide. (In part adapted from Bauer and Gergel' 1994 and Toda et al. 2007.)

Electrons are donated by NADPH to the reductase domain of the enzyme and proceed via FAD and FMN redox carriers to the oxygenase domain. They interact with the hem iron and $\mathrm{THB}_{4}$ at the active site to catalyze the reaction of oxygen with L-arginine, generating citrulline and $\mathrm{NO}$ as products (Alderton et al. 2001). NO then diffuses to smooth muscle cells, where it binds to its principal receptor, the soluble guanylyl cyclase (sGC), which in turn converts guanosine5'-triphosphate (GTP) into cGMP and consequently induces vascular smooth muscle relaxation and vasodilatation (Figs. $2,5)$. Both the enzyme activity of eNOS and the NO evoked relaxation require the presence of NADPH and CaM (Büsse and Mülsch 1990) and are dependent on the presence of $\mathrm{Ca}^{2+}$ (Singer and Peach 1982; Long and Stone 1985).

Due to its acylation, eNOS has been found to be targeted to plasmalemmal caveolae and Golgi membranes, where its activity is the highest (Oess et al. 2006). Localization to this microdomain is likely to optimize eNOS activation and extracellular release of NO. This targeting is a complex process depending on co-translational $\mathrm{N}$-myristoylation at glycine 2 and post-translational cysteine palmitoylation at positions 15 and 26 of the enzyme (Fulton et al. 2001; Govers and Rabelink 
2001), as well as on protein-protein interactions with caveolin-1 (Cav-1) (Feron et al. 1996), heat shock protein (Hsp90) (Garcia-Cardena et al. 1996; Young et al. 1997; Brouet et al. 2001), and the survival promoting serine/threonine protein kinase B (Akt) (Fulton et al. 1999; Luo et al. 2000). On stimulation of cells with various agonists, CaM and Hsp90 are recruited, the Cav-1 inhibitory clamp is displaced and phosphorylation by Akt results in modulation of eNOS catalysis and NO release (Fontana et al. 2002). An important means of regulating eNOS activity appears to be its phosphorylation (Dimmeler et al. 1999; Fulton et al. 1999). Phosphorylation and dephosphorylation complement acylation and CaM as major post-translational regulatory influences on eNOS activity. Serine (Ser) and threonine (Thr) are key residues in eNOS: phosphorylations at Ser 1177, Ser 635, and Ser 617 are stimulatory, while phosphorylations at Thr 495 and Ser 116 are inhibitory (Moncada et al. 1989; Bauer et al. 2003). ADMA is described in the literature as an endogenous inhibitor of NO synthase. Elevated plasma ADMA levels are associated with cardiovascular complications, such as stroke, congestive heart failure and peripheral arterial disease, so that ADMA is considered a biochemical marker of cardiovascular risk (Cooke 2005). Metabolism of ADMA is facilitated by DDAH (Achan et al. 2003) (Fig. 2). While the dimeric form of eNOS catalyzes the synthesis of NO, the monomeric form catalyzes the synthesis of highly active oxygen species - including superoxide anion radical $\left(\mathrm{O}_{2}{ }^{--}\right)$(Zou et al. 2002). In the absence of $\mathrm{THB}_{4}$, eNOS becomes "uncoupled" and its catalysis is altered so that rather $\mathrm{O}_{2}{ }^{--}$than $\mathrm{NO}$ is produced. Various pathological stimuli, including $\mathrm{AT}_{\mathrm{II}}$, diabetes and hypercholesterolemia have also been associated with eNOS uncoupling (Harrison et al. 2006).

In both the central and peripheral nervous system, nNOS produces NO, performs a role in cell communication and is associated with plasma membranes (Lamas et al. 1992). While only eNOS is detectable in healthy human vessels with standard techniques, all three isoforms are present in atherosclerotic lesions (Schödela et al. 2009). Loesch and Burnstock (1998) found nNOS protein also in endothelial cells of the rat basilary artery and Huang et al. (2002) detected nNOS in the endothelial cell layer of coronary arteries of eNOS knockout mice, but not in wild type mice. In eNOS knockout mice, nNOS was shown to be responsible for flow induced dilatation of coronary arteries. Wilcox et al. (1997) described nNOS protein colocalized with smooth muscle cells in the media and neointima. In the human atherosclerotic plaque, nNOS is expressed in smooth muscle cells, macrophages and endothelial cells (Wilcox et al. 1997) and nNOS might be a novel anti-atherogenic factor (Tsutsui 2004). In rat vascular smooth muscle cells, nNOS expression is increased under conditions of high intraluminal pressure, following hypoxia and stimulation with platelet derived growth factor (Ebrahimian et al. 2003; Schödela et al. 2009). Thus under specific conditions as shear stress, hypoxia, and presence of growth factors, nNOS upregulation occurs also in vascular smooth muscles.

In a classical view, in contrast to cNOSs, evidence for „baseline” expression of the cytosolic iNOS isoform is normally elusive. Presumably due to its tight non-covalent interaction with $\mathrm{Ca}^{2+}{ }_{-} \mathrm{CaM}$ complex, iNOS has been described as $\mathrm{Ca}^{2+}$-independent (Kibbe et al. 1999). For a longer period of time, iNOS is expressed upon activation by a variety of factors, including the pro-inflammatory cytokines, e.g. IL, TNF- $\alpha$, interferon-gamma (IFN- $\gamma$ ) and lipopolysaccharide (Weinberg et al. 2007). Once iNOS is upregulated in phagocytes (monocytes, macrophages, and neutrophils) or hepatocytes, and with potent signals also in epithelial cells and neurons, it always synthesizes large amounts of $\mathrm{NO}$ and an inflammation mediated stimulation develops. NO has been demonstrated to activate interferon regulatory factor 1 (IRF-1) and NF- $\kappa \mathrm{B}$ in peripheral blood mononuclear cells, as an important transcription factor in iNOS gene expression in response to inflammation (Kaibori et al. 1999). These properties may define the roles of iNOS in host immunity, enabling its participation in anti-microbial and anti-tumor activities as part of the oxidative burst of macrophages (Chatterjee and Catravas 2008). Output of NO might serve as an "inflammometer", a breath test of exhaled NO serves as an indicator of airway inflammation in diseases like asthma, COPD (Redington 2006), etc.

NO may itself regulate NOS expression and activity. Specifically, NO has been shown to play an important negative feedback regulatory role on eNOS and vascular endothelial cell function. This process, known formally as $S$-nitrozation (referred to as $S$-nitrosylation by many in the field), has been shown to reversibly inhibit eNOS activity in vascular endothelial cells. Nitroanalogs of L-arginine (e.g. $\mathrm{N}$-monomethyl-L-arginine, $\mathrm{N}$-nitro-L-arginine, L-canavanine, $\mathrm{L}$-arginine oxalate, $\mathrm{N}$-propyl-L-arginine) inhibit both basal and evoked NO synthesis. These responses are eliminated by supplementation of L- but not D-arginine (Gold et al. 1989; Ress et al. 1989). Introduction of NOS inhibitors (Palmer et al. 1988) greatly contributed to clarifying the physiological roles of NO not only in the endothelium and vasculature but also in the immune system, the gastric mucosa (Lanas 2008), in the central (Garthwaite et al. 1988) and peripheral nervous system, namely in the nonadrenergic-noncholinergic (NANC) inhibitory transmission in gut, airways, lower urinary tract, corpora cavernosa and some blood vessels (Boeckstaens et al. 1990; Bauer 1993; Lefebvre 1995; Toda and Okamura 2003; Toda and Herman 2005).

The hypothesized beneficial effects of increased iNOS expression may be transient, because this high-output iNOS usually occurs in an oxidative environment. The produced 


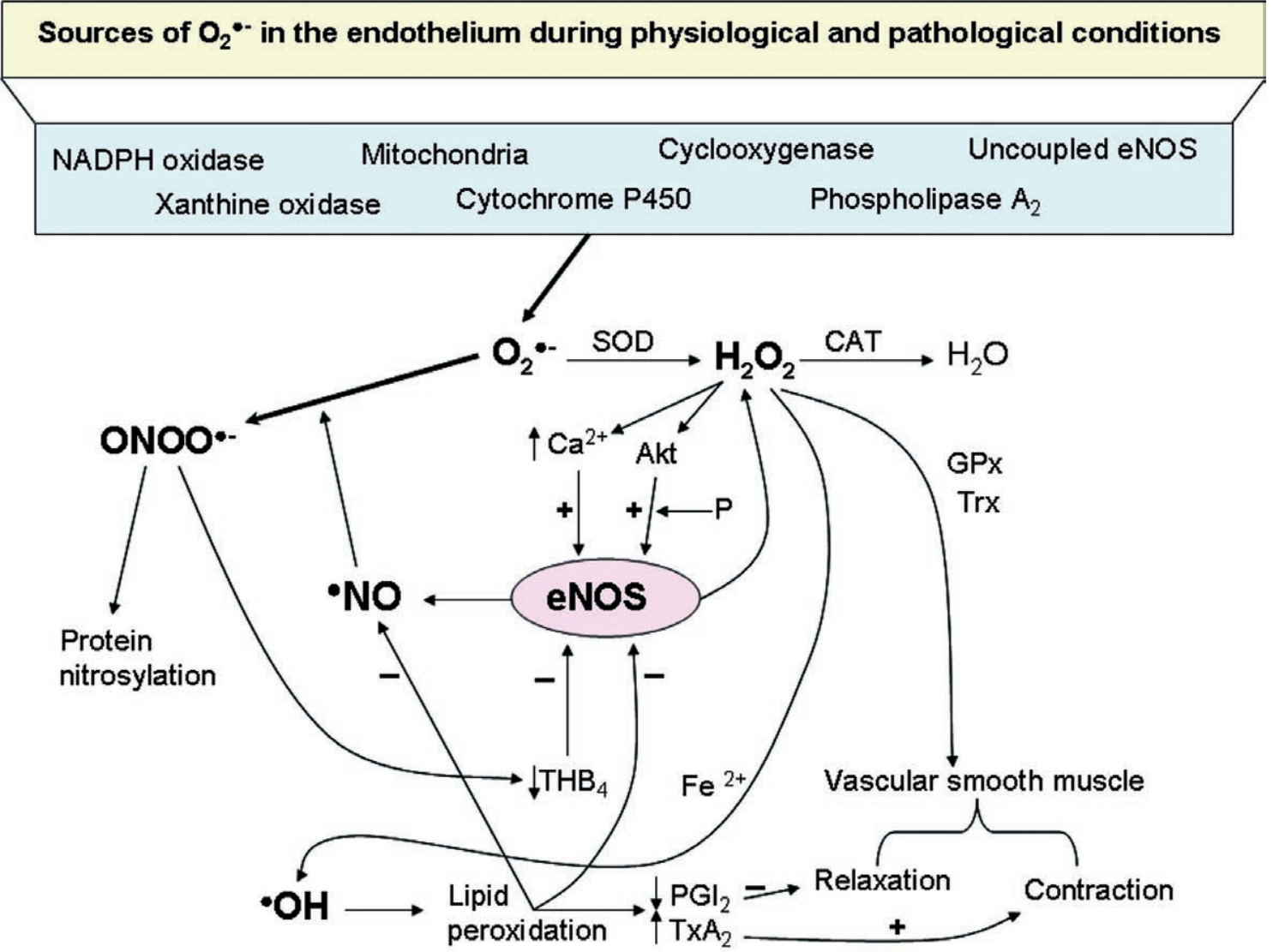

Figure 3. Sources of ROS, interaction of $\mathrm{O}_{2}{ }^{--}$with $\mathrm{NO}$ and the effects of produced $\mathrm{ONOO}^{--}$in the endothelium during physiological and pathological conditions. $\mathrm{O}_{2}{ }^{-}$, superoxide anion radical; ${ }^{\circ} \mathrm{NO}$, nitric oxide radical; $\mathrm{ONOO}{ }^{\bullet-}$, peroxynitrite; SOD, superoxide dismutase; Akt, serine/threonine protein kinase; CAT, catalase; GPx, glutathione peroxidase; Trx, thioredoxin; $\mathrm{THB}_{4},(6 R)-5,6,7,8$-tetrahydrobiopterin; $\mathrm{PGI}_{2}$, prostaglandin $\mathrm{I}_{2}$ (prostacyclin); TxA 2 , thromboxane $\mathrm{A}_{2}$. (In part adapted from Sena and Seica 2010.)

$\mathrm{NO}$ may react with $\mathrm{O}_{2}{ }^{\bullet-}$ to yield peroxynitrite $\left(\mathrm{ONOO}^{\bullet-}\right)$, a highly reactive compound, participating not only in mammalian defense mechanisms against microorganisms, but also in the pathophysiology during overexposure of tissues to radicals or other reactive species (Muijsers et al. 1997). Such conditions may then contribute to the pathogenesis of vascular injury and participate in the development of atherosclerosis, hypertension, ischemia/reperfusion, etc. (Beckman and Koppenol 1996; Pacher et al. 2007; Ginnan et al. 2008; Pacher and Szabo 2008).

High concentrations of ROS produce further oxidation products, e.g. lipid peroxides (LPO), suppress generation of prostaglandin $\mathrm{I}_{2}$ (prostacyclin, $\mathrm{PGI}_{2}$ ), and attenuate the activity of PGG/PGH and $\mathrm{PGI}_{2}$ as well as that of eNOS in endothelial cells. Concurrently, prevalence of ROS-resistant thromboxane- $\mathrm{A}_{2}\left(\mathrm{TxA}_{2}\right)$ activity occurs. These processes result then in loss of vasodilatation and development of vasoconstriction (Beny and Brunet 1988; Katušic and Vanhoutte 1989; Vanhoutte et al. 1991) (Fig. 3).

\section{NO as transmitter}

In contrast to most hormones, neurotransmitters and growth factors that transmit signals between cells and act through specific protein receptors associated with the plasma membrane, NO diffuses out of the cell that generates it as a radical or bound to a carrier molecule, e.g. amino acid L-cysteine (Myers et al. 1990) and passes through the plasma membrane into the target cells, where it interacts with specific molecular targets. The best-characterized targets/receptors of NO are either ironcontaining enzymes and proteins with a heme group, amino acids or iron-sulfur complexes. Binding of NO to these targets either activates or inactivates them (Fig. 4). As a radical, ${ }^{\circ} \mathrm{NO}$ possesses high reactivity and interaction with other reactive species, e.g. superoxide anion radical $\left(\mathrm{O}_{2}{ }^{--}\right)$(Figs. 3, 4).

Based on the above mentioned findings, NO is now regarded as an intercellular messenger or transmitter that plays a pivotal role in circulatory regulations, including its influence on the cell cycle and apoptosis, as well as vasodilatation, in- 


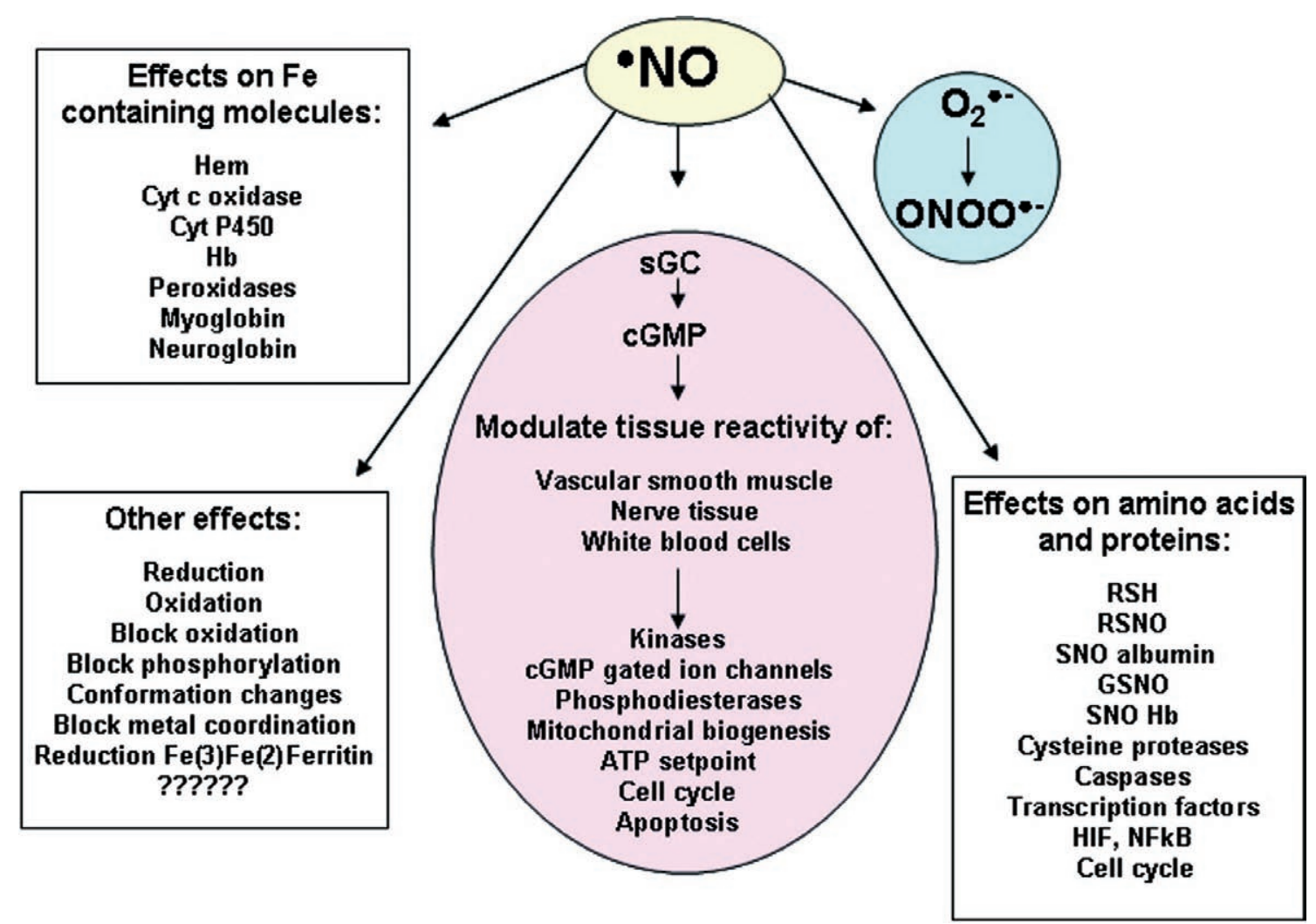

Figure 4. Targets of the nitric oxide radical $\left({ }^{\circ} \mathrm{NO}\right)$ in effector cells. $\mathrm{O}_{2}{ }^{--}$, superoxide anion radical; ONOO ${ }^{\bullet-}$, peroxynitrite; cyt, cytochrome; sGC, soluble guanylate cyclase; cGMP, cyclic 3'-5'-guanosine monophosphate; ATP, adenosine triphosphate; RSH, glutathione; RSNO, S-nitrosothiols; SNO albumin, S-nitroso-albumin; GSNO, nitroso-L-glutathione; SNO Hb, S-nitrosohemoglobin; HIF, hypoxia inducible factor; NF-kB, nuclear factor kappa B. (In part adapted from Henry et al. 1993.)

creased blood flow, lowered systemic blood pressure, inhibitions of platelet aggregation and adhesion, leukocyte adhesion and transmigration, smooth muscle proliferation, and low-density lipoprotein oxidation (Moncada et al. 1991; Ignarro 2000).

\section{Vascular effects of NO}

Endothelial cells produce and release factors which either contract (e.g. EDCF, ET, AT $_{\mathrm{II}}, \mathrm{Hi}$ ) or relax (e.g. NO, EDHF, $\mathrm{PGI}_{2}$ ) the vascular smooth muscle (Yanagisawa et al. 1988; Furchgott and Vanhoutte 1989; Vane et al. 1990; Rubanyi 1991a; Lüscher et al. 1992; Münzel 2008). Their effects result mainly from significant alterations in the concentration of free $\left[\mathrm{Ca}^{2+}\right]_{\mathrm{i}}$, thus playing an influential role in the maintenance and regulation of vascular smooth muscle tone (Stankevičius et al. 2003; Félétou et al. 2010).

As shown in Fig. 5, the vascular smooth muscle relaxation evoked by acetylcholine, A 23187, histamine, electric stimulation, and a number of other biologically active substances, e.g. adrenaline, noradrenaline, histamine, serotonin, ATP, adenosine, substance $\mathrm{P}$, arginine vasopressin, bradykinin, thrombin, $\mathrm{Ca}^{2+}$-ionophore A 23187 , etc. is associated with an amplified production and/or release of NO (Furchgott and Zawadski 1980; Zawadski et al. 1980; Vanhoutte and Eber 1991; Buga and Ignarro 1992). In the L-arginine-eNOScGMP-phosphodiesterase-5 ( $\left.\mathrm{PDE}_{5}\right)$ pathway, NO diffuses to and through the plasma membrane of vascular smooth muscle cells and binds to the iron in the heme group of sGC. The activated enzyme consequently produces cGMP from GTP (Rappoport et al. 1983; Forstermann et al. 1986; Buga and Ignarro 1992), which activates cyclic nucleotidedependent protein kinase $\mathrm{G}\left(\mathrm{PK}_{\mathrm{G}}\right)$ or cGMP-dependent $\mathrm{PK}_{\mathrm{I}}$ $\left(\mathrm{cGK}_{\mathrm{I}}\right)$. The latter phosphorylates a number of proteins that regulate $\mathrm{Ca}^{2+}$ homeostasis. The cGMP mediated relaxation results from the reduced $\mathrm{Ca}^{2+}{ }_{\mathrm{i}}$ mobilization in (Godfraind et al. 1985), reduced $\mathrm{Ca}^{2+}{ }_{\mathrm{o}}$ influx to (Collins et al. 1988; Blatter and Wier 1994) and facilitated efflux of $\mathrm{Ca}^{2+}{ }_{i}$ from the smooth muscle cells. These molecular events are culminating in reduction of the free cytosolic $\mathrm{Ca}^{2+}$ concentration and in decrease of the sensitivity of the contractile system to $\mathrm{Ca}^{2+}$ (Carvajal et al. 2000). Moreover, the following processes may 


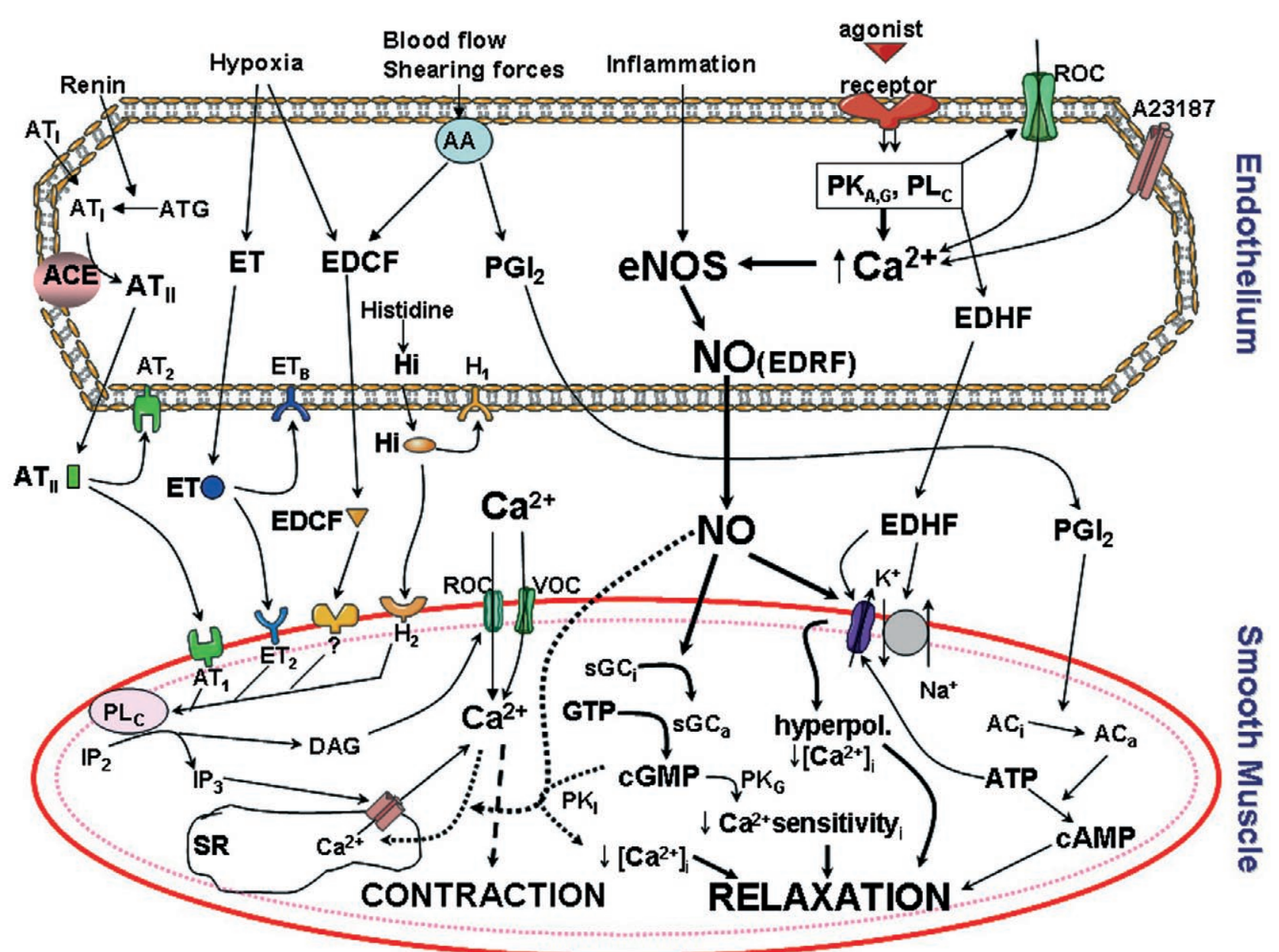

Figure 5. Production of endothelial factors that affect vascular smooth muscle tone with special attention to the actions of nitric oxide $(\mathrm{NO})$. Agonists $(\nabla)$, acetylcholine, adrenaline/noradrenaline, histamine, arginine/vasopressin, substance P, bradykinin, adenosine/adenosine triphosphate, serotonin and thrombin act on their corresponding membrane receptors $\left(\Omega, \mathrm{M}_{2}\right.$-muscarinic; $\alpha_{2}$-adrenergic; $\mathrm{H}_{2}$-histaminergic; $\mathrm{AVPR}_{1}$-arginine-vasopressin, neurokinin, $\mathrm{B}_{2}$-bradykinin, $\mathrm{P}_{2}$-purinergic, $5 \mathrm{HT}_{1}$-serotonergic, thrombin receptors, respectively) and on $\mathrm{Ca}^{2+}$ channels $\left(\mathrm{Ca}^{2+}\right.$ ionophore- $\left.\mathrm{A}_{23187}\right)$, increase $\left[\mathrm{Ca}^{2+}\right]_{\mathrm{i}}$, and consequently, similarly to the effect of inflammation, they increase NO synthesis via activation of eNOS (endothelial nitric oxide synthase) and produce also EDHF (endothelium derived hyperpolarizing factor). Other mechanical and chemical influences (e.g. blood flow, shearing forces, hypoxia, renin) result in increased production of additional endothelial constituents, both relaxatory (e.g. $\mathrm{PGI}_{2}$, prostacyclin) and contractile ( $\mathrm{AT}_{\mathrm{I} / \mathrm{II}}$, angiotensin I/II; ET, endothelin; EDCF, endothelium derived contracting factor). Further abbreviations are: AA, arachidonic acid; ROC/VOC, receptor/voltage operated $\mathrm{Ca}^{2+}$ channels; ATG, angiotensinogen; $\mathrm{PK}_{\mathrm{A} / \mathrm{G} / \mathrm{I}}$, protein kinase A/G/I; PLC, phospholipase C; ACE, angiotensin converting enzyme; receptors of angiotensin - $\mathrm{AT}_{1,2}$, of endothelin - $\mathrm{ET}_{\mathrm{B}, 2}$, of histamine $-\mathrm{H}_{1,2} ; \mathrm{sGC}_{\mathrm{i} / \mathrm{a}}$, soluble guanylate cyclase inactive/active; GTP, guanosine triphosphate; GMP, guanosine monophosphate; cGMP, cyclic 3'-5'-guanosine monophosphate; $\mathrm{AC}_{\mathrm{i} / \mathrm{a}}$, adenylate cyclase inactive/active; ATP, adenosine triphosphate; $\mathrm{IP}_{2}$, inositol-4,5-bisphosphate; $\mathrm{IP}_{3}$, inositol-1,4,5-trisphosphate; DAG, diacyl glycerol; cAMP, 3',5' - cyclic adenosine monophosphate; SR, sarcoplasmic reticulum. (In part adapted from Bauer and Gergel' 1994, Stankevičius et al. 2003 and Félétou et al. 2010.)

also participate in smooth muscle relaxation: membrane hyperpolarization due to activation of potassium channels, activation of the enzyme that dephosphorylates myosin light chains and the myosin light chain phosphatase, further reduction of sensitivity of myosin phosphorylation by cGMP dependent protein kinases (Rappoport et al. 1983; Rembold
1992), and/or uncoupling of the contracting mechanisms from myosin phosphorylation (Rembold 1992).

The sGC inhibitor methylene blue attenuates both the production of cGMP and muscle relaxation (Lüscher 1991). Endothelium removal prevents acetylcholine and A 23187 from being effective (Fig. 1), while it does not influence 
the action of NO donors (e.g. nitroglycerine or sodium nitroprusside; Rappoport and Murad 1983). This fact proves that NO released from the endothelium relaxes the vessels by means of cGMP.

Not only does NO modulate vasomotor tone, induce vasodilatation, increase regional blood perfusion and lower systemic blood pressure but it also inhibits expression and activity of matrix metalloproteinases (MMPs), leading to extracellular matrix remodeling and increased smooth muscle cell growth, permitting cell migration and proliferation, altering atherosclerotic plaque stability and allowing cardiac and vascular smooth muscle proliferation and hypertrophy (Upchurch et al. 2001; Stocker and Keaney 2004; Wang et al. 2005). It inhibits expression of MCP-1, reduces vascular cell adhesion molecule-1 (VCAM-1) expression and prevents propagation of lipid oxidation (Cai and Harrison 2000). The endothelium possesses also an anticoagulation property, decreases platelet aggregation, affects inflammation, pain perception and neurotransmission (Bauer 1993; Lowenstein et al. 1994; Bauer et al. 2000; Toda and Okamura 2003; Mackenzie et al. 2008).

During aggregation and adhesion of platelets to their corresponding receptors on the endothelial cell surface, the platelets release ADP, serotonin and thrombin, which amplify the production of NO, with consequent increase of blood flow due to the removal of vasospasms, dilatation of vessels (Vanhoutte and Hauston 1985), and suppressed platelet aggregability (Radomski et al. 1987; Hogan et al. 1988).

Contrary to ROS, NO may also attenuate the adhesion of leukocytes and act as an extracellular scavenger of $\mathrm{O}_{2}{ }^{--}$pro-

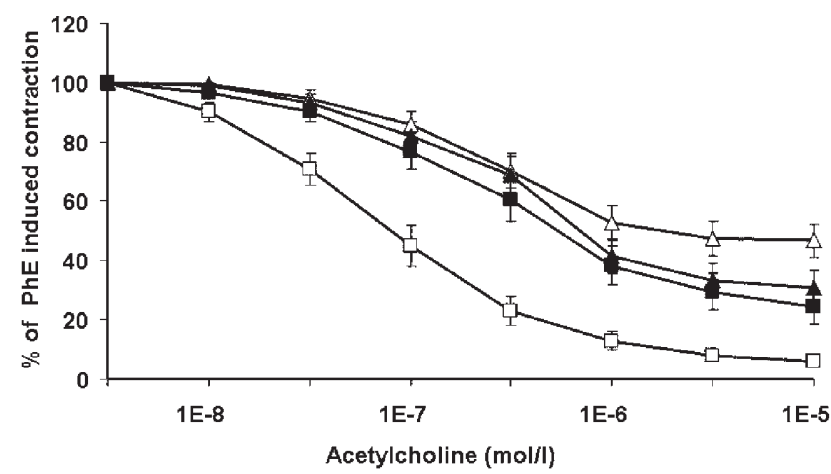

Figure 6. Effects of 60-min ischemia followed by 30-min reperfusion $(\mathrm{I} / \mathrm{R})$ on responses of phenylephrine $(\mathrm{PhE})$-precontracted $(1 \mu \mathrm{mol} / \mathrm{l})$ rings of the superior mesenteric artery to acetylcholine. Data are means \pm S.E.M of 8 experiments. Open squares are preparations from sham controls; full squares preparations from animals with I/R; open triangles preparations from sham controls after blockade of NO synthase (NOS) and prostaglandins (PGs); full triangles preparations from animals with $\mathrm{I} / \mathrm{R}$ after blockade of NOS and PGs. duced by leukocytes, preserving thus the integrity of cells as a chemical barrier (Rubanyi et al. 1991) also under conditions such as e.g. ischemia/reperfusion.

Not only reduction in NO bioavailability but also its excess amounts can damage host cells, causing e.g. neurotoxicity during stroke and hypotension associated with sepsis. Under conditions of sepsis, endothelial dysfunction is probably an early impairment of vasodilator responses to mediators which depend upon an intact endothelium, as well as to shear stress and to vessel occlusion. If the formation of $\mathrm{NO}$ by iNOS is to 'replace' the loss which is a consequence of early endothelial dysfunction, then the situation would be similar to the role of catecholamines in shock (Parratt 1998, Funk et al. 2009).

\section{Some examples of pathologies that involve NO}

\section{Increased production of angiotensin}

$\mathrm{AT}_{\mathrm{II}}$, a potent vasoconstrictor is produced from $\mathrm{AT}_{\mathrm{I}}$ by angiotensin converting enzyme (ACE) located at the surface of the endothelium (Figs. 2, 5). The somatic ACE isoenzyme is expressed in many tissues, e.g. mainly in vascular endothelial cells present in the lung. It participates not only in $\mathrm{AT}_{\mathrm{II}}$ production but is involved also in inactivation of bradykinin, a potent vasodilator. $\mathrm{AT}_{\mathrm{II}}$ affects vascular smooth muscles through $\mathrm{AT}_{1}, \mathrm{AT}_{2}$, and $\mathrm{AT}_{4}$ receptors, which are differently involved in NO synthesis and alter vascular contractility by various mechanisms in relation to NO. Activation of $\mathrm{AT}_{1}$ receptors causes vascular smooth muscle contraction and also elicits vasoconstriction indirectly by forming ROS (particularly $\mathrm{O}_{2}{ }^{--}$) that scavenge NO. Activation of the other receptor subtypes in endothelial cells, e.g. $\mathrm{AT}_{2}$ leads to generation of vasodilating prostaglandins $\left(\mathrm{PGI}_{2}\right.$ and $\left.\mathrm{PGE}_{2}\right)$ (Suzuki et al. 1984; Ferrario 1993; Toda et al. 2007).

Neither are interactions of $\mathrm{AT}_{\mathrm{II}}$ and endothelium-derived relaxing factors other than NO, such as EDHF (Fig. 5), negligible (Roks 2002; Fujiki et al. 2005). There are several candidates for EDHF, including epoxyeicosatrienoic acids, gap junctions, $\mathrm{K}^{+}$ions and hydrogen peroxide $\left(\mathrm{H}_{2} \mathrm{O}_{2}\right)$ (Shimokava and Matoba 2004; Fujiki et al. 2005). Thus imbalanced functioning of $\mathrm{NO}$ or $\mathrm{EDHF} / \mathrm{H}_{2} \mathrm{O}_{2}$ and $\mathrm{AT}$ II in the vasculature is considered to be one of the main pathogenic factors in cardiovascular diseases. Increased availability of NO is one of the most important pharmacological mechanisms underlying the beneficial actions of drugs that inhibit the synthesis and action of $\mathrm{AT}_{\mathrm{II}}$ and it is essential in treating circulatory and metabolic dysfunctions, including hypertension and diabetes mellitus (Toda et al. 2007).

A large body of data suggests that there is crosstalk at multiple levels between the signal transduction pathways that mediate insulin and $\mathrm{AT}_{\mathrm{II}}$ actions. Early insulin signal- 
ing steps are impaired in essential hypertension. $\mathrm{AT}_{\mathrm{II}}$ acting through the $\mathrm{AT}_{1}$ receptor can inhibit insulin-induced NO production and enhances the activity of NADPH oxidase, leading to increased ROS generation. Inhibition of the renin-angiotensin system improves insulin sensitivity and decreases the incidence of type 2 diabetes $\left(\mathrm{TD}_{2}\right)$ (Muscogiuri et al. 2008).

\section{Increased lipid peroxidation and oxidized low-density lipoproteins}

Increased plasma LPO were found as risk factors in various diseases, such as hypertension, atherosclerosis, eclampsia gravidarum, diabetes, etc. (Hennig and Chow; 1988; Esterbauer et al. 1989; Stam et al. 1989; Steinberg et al. 1989; Rumley et al. 2004). DiCorleto and Chisalm (1986), Palinski et al. (1989), Piotrowski et al. (1990), Glovind et al. (1992) anticipated that ROS produced by macrophages and white blood cells along with an increased local concentration of oxidized low-density lipoproteins (oxLDL) give rise to endothelial damage as a first step of atheromatous plaque formation and altered vessel function. The products of lipid peroxidation accumulated in endothelial cells (Hennig and Chow 1988) inhibit eNOS (Fig. 3). They inactivate NO, $\mathrm{PGI}_{2}$, sGC, and in activated macrophages also iNOS (Yang et al. 1994). The above mentioned effects thus result in increased adhesion of neutrophils and platelets and in their increased aggregability, further in smooth muscle proliferation, reduced actions of endogenous $\mathrm{NO}$, and in decreased effectivity of exogenous nitrites and of nitroso vasodilators (Schmidt et al. 1992).

Oxidized LDL induces interaction of endothelial cells with leukocytes and macrophages. Due to stimulation of biosynthesis of the intercellular adhesion molecule-1 (ICAM-1) and of E-selectin, this interaction participates in the genesis of angiopathy (Takei et al. 1998). In a larger amount, modified LDL molecules represent the main source of lipids for monocytes participating in lipid deposit formation in the subendothelial space. As a consequence of cell-to-cell and cell-to-matrix interactions, the activated endothelial cells, monocytes and macrophages, along with changes in the interstitial tissue, participate in fibrous plaque formation.

\section{Ischemia / reperfusion (I/R)-induced injury in the endothe- lium}

I/R is paradoxical aggravation of cellular dysfunction following restitution of blood flow to previously ischemic tissues. Endothelial cells appear to be particularly vulnerable to the deleterious effects of hypoxia/ischemia or anoxia (cNOS is suppressed). Reperfusion-induced reoxygenation, which is essential for recovery of ischemic tissues, paradoxically causes further damage (reduced production of NO, neu- trophil activation and infiltration, oxidative burst, increased ROS production, lipid peroxidation, eicosanoid generation, complement activation, cytokine generation, etc.) to a wide range of organs including the heart, lung, brain, kidney, gut, and skeletal muscle (Rubanyi and Vanhoutte 1985; Grisham et al. 1998; Khanna et al. 2005; Tripathi and Misra 2009).

I/R-induced vascular dysfunction has been found in the pathophysiology of various diseases and organ injuries, even during a variety of medical procedures, such as thrombolytic therapy, organ transplantation, coronary angioplasty, cardiopulmonary bypass, etc. In the postischemic tissue, the observed changes possess molecular and biochemical characteristics of inflammatory reactions (Granger 1999; Neary and Redmond 1999) accompanied by functional and morphological alterations in vessels. Elevated plasma cholesterol aggravates the reaction elicited by I/R. The I/R-evoked vascular dysfunctions include impaired endothelium-dependent NO-mediated relaxation (Fig. 6), cell swelling, loss of pinocytotic vesicles, lifting of endothelial cells from the underlying basement membrane, increased filtration of fluid into the interstitium, reduced number of perfused capillaries and attachment (adherence) of activated leukocytes (primarily neutrophils) to the endothelial cell surface (Nosálová et al. 2007).

Xanthine oxidase activity, which increases following I/R, may generate not only $\mathrm{O}_{2}{ }^{--}$but also chemotactic factors leading to sequestration and firing of inflammatory leukocytes locally as well as at distant sites, thereby facilitating neutrophilendothelial cell adhesion and neutrophil-mediated vascular and tissue injury at the site of the primary ischemia and also far away from it. $\mathrm{ROS}\left(\mathrm{O}_{2}{ }^{\bullet}, \mathrm{H}_{2} \mathrm{O}_{2}\right.$ and hypochlorous acid) overproduction (both by endothelial cells and leukocytes) and reduced NO bioavailability are thus important determi-

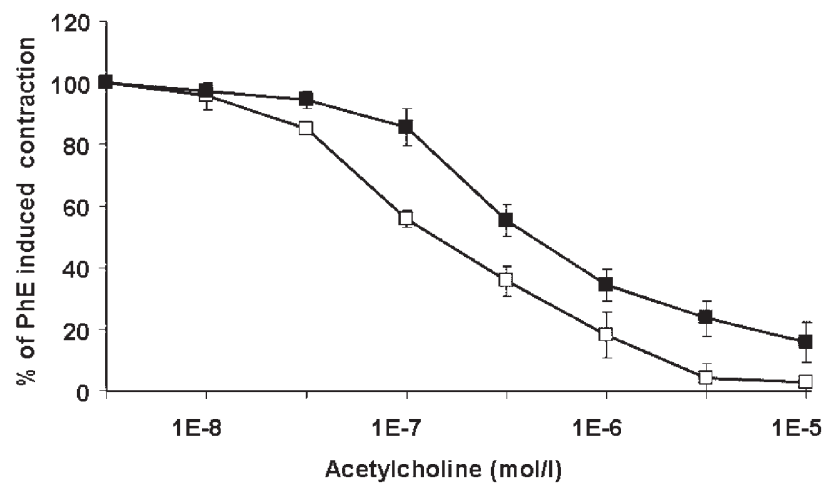

Figure 7. Effects of streptozotocine (STZ)-induced diabetes lasting 10 weeks on responses of phenylephrine (PhE)-precontracted $(1 \mu \mathrm{mol} / \mathrm{l})$ rings of the superior mesenteric artery to acetylcholine. Data are means \pm S.E.M of 8 experiments. Open squares are preparations from controls; full squares preparations from animals treated with STZ. 
nants of the inflammatory responses observed in vessels after I/R (Granger 1988; Carden and Granger 2000).

Khanna et al. (2005) have suggested that the I/R-induced vascular dysfunctions result mainly from a subtle interplay between $\mathrm{O}_{2}{ }^{--}$and NO. Under physiologic conditions, NO is produced far in excess of $\mathrm{O}_{2}{ }^{--}$. This allows $\mathrm{NO}$ to scavenge and clear endothelial cells of low concentrations of $\mathrm{O}_{2}{ }^{\bullet-}$, to prevent platelet aggregation, thrombus formation, as well as adhesive interactions between endothelial and inflammatory cells. According to these authors, two modes of NO-mediated mechanisms contribute to tissue injury. A transient activation followed by a decrease in eNOS occurs in the early stages of reperfusion due to the progression of endothelial dysfunction. This contributes to vascular dysfunction, neutrophil infiltration and activation. L-arginine and $\mathrm{THB}_{4}$ deficiency may be responsible in part for the concurrent reductions in NO production and eNOS activity. The low levels of NO can be rapidly quenched by the abundant amounts of $\mathrm{O}_{2}{ }^{--}$, which has implications for leukocyte/endothelial interactions. Subsequently, endothelial-dependent vasodilatation becomes compromised. In the later stages of reperfusion, cytokine-induced expression of iNOS, initially in mast cells and later in neutrophils and macrophages, also contributes to $\mathrm{ONOO}^{\bullet-}$ production and development of further tissue injury.

Evidence that I/R elicits oxidant-mediated tissue injury is supported by the adaptational responses to brief periods of ischemia in different tissues. In endothelial cells, preconditioning augments the production of NO during a second ischemic (anoxic) challenge, which contributes to the delayed preconditioning response (Korthuis et al. 1998, Tsai et al. 2004). Moreover, Gorbe et al. (2010) showed that $\mathrm{NO}$ is protective against I/R-induced injury of myocytes. They found that the cGMP-inducing agents (cGMP analog 8-bromo-cGMP, direct NO-donor S-nitroso-N-acetylpenicillamine and B-type natriuretic peptide) possess protective effect in $I / R$, which is abolished by the selective $P K_{G}$ inhibitor KT-5823. This was the first demonstration that elevated cGMP, produced either by the sGC or the particulate guanylate cyclase (pGC), exerts cytoprotective effects via a common downstream signaling pathway involving $\mathrm{PK}_{\mathrm{G}}$ activation.

Maslov et al. (2009) summarizing cardioprotective effects of NO described two components of its actions, a rapid and a delayed one. In the rapid component not only eNOS but also sGC, cGMP, $\mathrm{PK}_{\mathrm{G}}$, protein kinase $\mathrm{C}\left(\mathrm{PK}_{\mathrm{C}}\right)$, phosphatidylinositol 3-kinase ( $\mathrm{PI}_{3}$-kinase), Akt-kinase, mitochondrial ATP-sensitive $\mathrm{K}^{+}$-channels, ROS and mitochondrial permeability transition (MPT) pore are involved. The delayed cardioprotective effect of NO requires synthesis of NOS proteins de novo and involvement of transcription factors $\mathrm{NF}-\kappa \mathrm{B}$, signal transduction and transcription protein $1 / 3$ $\left(\mathrm{STAT}_{1 / 3}\right)$, hypoxia-inducible factor $1\left(\mathrm{HIF}_{1}\right), \mathrm{ONOO}^{\circ-}$,
cGMP, $\mathrm{PK}_{\mathrm{G}}, \mathrm{PK}_{\mathrm{C}}$, Src-kinase, p38-kinase, and extracellular signal regulated kinase (ERK-kinase). The authors are of the opinion that the protective impact of NO depends on enhancement of the expression of NOS, $\mathrm{PGI}_{2}$, and chemokine $\mathrm{B}$ lymphocyte chemoattractant $2\left(\mathrm{Blc}_{2}\right)$ protein, which inhibits the MPT pore.

\section{Progression of diabetes mellitus and endothelial dysfunction}

Functional impairment of endothelial activity precedes the development of morphological alterations during long-term development of diabetes. Since attenuated endotheliumdependent vasodilatation has been described in human diabetes and in animal models (De Vriese 2000), one of the major concerns in long-term management of the disease is the development of severe microvascular and macrovascular complications. Endothelial dysfunction results from reduced bioavailability of the vasodilator $\mathrm{NO}$, mainly due to the accelerated NO degradation by ROS. It is responsible for the excess morbidity and mortality associated with diabetes (Baynes 1991; Vanderjagt et al. 2001; Fowler 2008). The vascular dysfunctions in chronic diabetes involve endothelial cells, vascular smooth muscle cells (Fig. 7), and their interaction with circulating blood cells such as platelets, monocytes, and lymphocytes. In addition, the resulting vascular stiffening also includes adventitial cells as well as connective tissue. Impaired insulin receptor substrate-1 and $\mathrm{PI}_{3}$-kinase dependent signaling pathways result in decreased NO production in the endothelium and in diminished glucose transporter (GLUT-4) translocation in peripheral tissues, leading to peripheral insulin resistance (Jiang et al. 1999; Kim et al. 2006).

During vascular injury, the expression and function of iNOS is regulated by the production of ROS and RNS in smooth muscles in general and particularly by the generation of several isoforms of NADPH oxidase and of cytokines. Inflammation with increased ROS production plays a critical role in promoting smooth muscle cell migration and proliferation during vascular diseases, such as postangioplasty restenosis and atherosclerosis. Nonenzymatic glycosylation of plasma proteins may contribute to the excess risk of developing atherosclerosis in diabetes mellitus. In diabetes, high-density lipoprotein (HDL) is glycosylated at an increased level of glucose. Gly-ox-HDL markedly downregulates catalase (CAT) and $\mathrm{Cu}^{2+}, \mathrm{Zn}^{2+}$-superoxide dismutase (CuZn-SOD), suggesting $\mathrm{H}_{2} \mathrm{O}_{2}$ formation due to a disturbance involving oxidant and antioxidant enzyme balance. Gly-ox-HDL attenuates also the expression of eNOS, but not of iNOS, followed by decreased production of $\mathrm{NO}$ (Matsunaga et al. 2003).

Pharmacological control of oxidative stress and stimulation of NO release have proved to exert beneficial effects on vascular remodeling in experimental diabetic models 
(Spinetti et al. 2008). Although hyperglycemia, insulin resistance, hyperinsulinemia and dyslipidemia independently contribute to endothelial dysfunction via several distinct mechanisms, increased oxidative stress seems to be the first alteration triggering several others. Mechanisms proposed to explain glucose- and lipid-induced vascular alterations in diabetes include accelerated formation of advanced glycation end-products (AGEs), $\mathrm{PK}_{\mathrm{C}}$ activation, inflammatory signaling and oxidative stress. $\mathrm{PK}_{\mathrm{C}}$, a serine threonine kinase, was found to be activated in the endothelium under certain pathophysiological conditions and is associated with changes in blood flow, basement membrane thickening, extracellular matrix expansion, increases in vascular permeability, abnormal angiogenesis, excessive apoptosis and changes in enzymatic activity of e.g. $\mathrm{Na}^{+}-\mathrm{K}^{+}$-ATPase, $\mathrm{PI}_{3}$-kinase and mitogen-activated protein kinase (MAPK). Inhibition of $\mathrm{PK}_{C}$, especially of the $\beta_{1 / 2}$ isoform, has been reported to prevent or normalize many vascular abnormalities in the retina, aorta, heart, renal glomeruli, etc. (Gutterman 2002; Evcimen and King 2007). Insulin resistance with impaired $\mathrm{PI}_{3}$-kinase decreases insulin-mediated production of $\mathrm{NO}$ and reduces vasodilatation, capillary recruitment and antioxidant properties of the endothelium. Compensatory hyperinsulinemia enhances activation of intact MAPK pathways and contributes to pro-atherogenic events by increasing the secretion of ET-1, stimulating the expression of adhesion molecules such as VCAM- 1 and E-selectin, and by inducing production of ROS (Potenza et al. 2009).

Patients with $\mathrm{TD}_{2}$ diabetes have a decreased ability of insulin to increase endothelial $\mathrm{NO}$ release and have lower levels of NO than patients without diabetes (Chien et al. 2005). Coronary artery disease and erectile dysfunction are cardiovascular complications frequently occurring in patients with diabetes, obesity, and dyslipidemia. All these metabolic disorders are characterized by insulin resistance, defined as decreased sensitivity and/or responsiveness to metabolic actions of insulin and thus promoting glucose disposal. Insulin resistance is not only a hallmark of metabolic abnormalities but is also a prominent feature of hemodynamic disorders. Indeed, insulin-stimulated release of endothelial factors takes part in the physiological regulation of vascular function and altered insulin actions may profoundly affect cardiovascular homeostasis under the given metabolic derangement.

The signpost of impaired vascular reactivity is endothelial dysfunction, a condition in which the endothelium loses its physiological ability to produce the vasodilator NO (Potenza and Montagnani 2008). It is likely that chronic low-level inflammation plays an important role in developing endothelial dysfunction mainly through proinflammatory actions of TNF- $\alpha$, as one of the primary pathogenetic mechanisms responsible for the development of angiopathy in chronic diabetes (Andersen and Pedersen 2008). Decreased blood flow due to vascular damage causes diabetic patients to be more likely to develop neuropathy, non-healing ulcers, and to be at greater risk for vasculopathies. In macroangiopathy, fat and blood clots build up in the large blood vessels, stick to the vessel walls, block the flow of blood and lead to tissue necrosis and gangrene. Due to microangiopathy, ophthalmologic, neurologic and nephrologic complications may occur. Microangiopathies are characterized by roughed-up basal membrane, proliferation, focal desquamation and alteration in endothelium cell shape, stack of granulocytes and adherence of platelets to the endothelium (Pieper and Gross 1991). The wall of small blood vessels becomes so thick and weak that they bleed, leak protein, and reduce blood flow. Stenosis or clot formation impairs the flow of oxygen and is the cause of proliferative diabetic retinopathy, central and peripheral neuropathy and nephropathy. The NO-cGMP- $\mathrm{PDE}_{5}$ pathway plays moreover a key role in diabetic gastropathy and in the attenuated synaptic plasticity affecting learning, memory formation and long-term potentiation (Patil et al. 2006). Bulhak et al. (2009) reported that activation of the peroxisome proliferator-activated receptor $\alpha$ (PPAR- $\alpha)$ exerts cardioprotection against $\mathrm{I} / \mathrm{R}$ in $\mathrm{TD}_{2}$ diabetes, involving mechanisms related to NO production via the $\mathrm{PI}_{3}$-kinase/Akt (active human protein kinase, also called $\mathrm{PK}_{\mathrm{B}}$ ) pathway.

Glucose acts not only as antioxidant but also as prooxidant. Already under physiological conditions, and even more so in high concentrations, glucose generates ROS (namely $\mathrm{O}_{2}{ }^{\bullet-}, \mathrm{H}_{2} \mathrm{O}_{2}$ and ${ }^{\circ} \mathrm{OH}$ ) as a result of its auto-oxidation, metabolism, and formation of AGEs (Hunt et al. 1990; Leloup et al. 2009). Moreover, the markedly increased copper plasma concentrations in diabetes may also lead to oxidative stress (Wolf et al. 1991).

The insulin-degrading enzyme (IDE) is responsible for the degradation of a number of hormones and peptides, including insulin and amyloid $\beta\left(A_{\beta}\right)$. Protein S-nitrosylation is now recognized as a redox-dependent, cGMP-independent signaling component that mediates a variety of actions of NO. Cordes et al. (2009) have suggested the existence of a possible reversible mechanism of nitrosative stress by which inhibition of IDE contributes to pathological conditions, such as Alzheimer's disease and $\mathrm{TD}_{2}$ diabetes.

Blood vessel complications of diabetes were found to develop when the glucose concentrations exceeded $20 \mathrm{mmol} / \mathrm{l}$. The mechanisms of the effects of high glucose concentrations on endothelium-dependent vascular reactivity are not clear yet. It has been suggested that decreased production of $\mathrm{PGI}_{2}$ and $\mathrm{PGE}_{1}$, increased formation of vasocontractile prostaglandins and ROS, protein glycosylation, reduced output and impact of NO, activation of the renin-angiotensin system, as well as changes in $\alpha$-adrenergic receptors might be involved in these mechanisms (Baynes 1991; Pieper and Gross 1991; Getz 1993; Tesfamariam 1994; Muscogiuri et al. 2008). 
The complexity of the pathogenesis of diabetic vasculopathy implies that a reversal of endothelial dysfunction in diabetes is unlikely to occur as the result of a single intervention alone.

\section{Conclusion}

The vascular endothelium, a specialized type of epithelial tissue, a thin layer of cells that line the interior surface of blood vessels forming an interface between circulating blood and the vessel wall, is a complex structure that releases mediators with important paracrine and autocrine effects on vascular tone, blood pressure, platelet aggregation, thrombus formation, and atheroma development. Endothelial cells line the entire cardiovascular system and their vital role is to reduce turbulence of blood flow, to prevent blood clotting, to produce and to eliminate vasoactive substances.

Morphologic defects or loss of proper endothelial function are hallmarks for vascular diseases and often lead to atherosclerosis, hypertension, myocardial infarction, complications of diabetes mellitus, and further chronic diseases (Vane 1994), called also "endotheliopathies" (Mendelsohn and Loscalzo 1992; Walsh et al. 2009).

There are many and heterogenous mediators released by the endothelium, including NO, which contribute to "health or disease", depending on a proper functioning vascular endothelium. NO, a noxious unstable gas, a byproduct of automobile exhaust, electric power stations, and lightning, has been found also in living organisms and its role as endogenous signal transducer molecule has been proved. Recently, a great deal of evidence has accumulated showing that NO availability is one of the main mechanisms of "endothelial dysfunction". In many instances, the decreased availability of $\mathrm{NO}$ is either due to its reduced production by NOS or to an interaction with ROS. $\mathrm{O}_{2}{ }^{--}$with $\mathrm{NO}$, at a diffusion-limited rate, brings on the formation of $\mathrm{ONOO}^{\bullet-}$, a strong oxidant which does not only lead to the loss of beneficial effects of $\mathrm{NO}$ but it also promotes formation of an injurious molecule that can worsen the pathologic condition.

Endothelial dysfunction is at least in part a reversible disorder. Appropriate diet, smoking cessation, physical exercise, as well as antidiabetics, lipid-lowering and antihypertensive drugs, estrogen replacement therapy in postmenopausal women, inhibition of the renin-angiotensin system induce among many others improved endothelial function (Hamilton et al. 2007; Leung et al. 2008; Muscogiuri et al. 2008). Drugs, which influence some of the mechanisms involved in endothelium dysfunction, e.g. TNF- $\alpha$-blocking agents in rheumatoid arthritis (Fichtlscherer et al. 2001; Hurlimann et al. 2002), supplementation with antioxidants, such as glutathione (Prasad et al. 1999), $N$-acetylcysteine (Andrews et al. 2001) and vitamin C (Carr and Frei 2000) with a few exceptions (Raitakari et al. 2000; Duffy et al. 2001), as well as supplementation with L-arginine in wound healing (Shi et al. 2007), with $\mathrm{THB}_{4}$ in cardiovascular diseases (Katušic et al. 2008), or cGMP-inducing agents (cGMP analog 8-bromocGMP, direct NO-donor S-nitroso-N-acetylpenicillamine and B-type natriuretic peptide) in I/R (Gorbe et al. 2010) are novel and prospective approaches that might exert positive effects on diseases associated with endothelial dysfunction.

In addition, selective inhibitors of iNOS, e.g. aminoguanidine, appear to attenuate endotoxin-induced multiple organ dysfunction. It needs however to be determined precisely at what point during sepsis such selective inhibitors should be administered and their relative ability to selectively inhibit iNOS rather than cNOS is to be assumed (Parratt 1998; Stabile et al. 2010).

Acknowledgement. The authors would like to thank Dr. M. Kourilová for correcting the English and for her critical reading of the manuscript. This work was supported in part by the Slovak Grant Agency VEGA No. 2/0050/09 and APVV No. 51-017905.

\section{References}

Achan V., Broadhead M., Malaki M., Whitley G., Leiper J., MacAllister R., Vallance P. (2003): Asymmetric dimethylarginine causes hypertension and cardiac dysfunction in humans and is actively metabolized by dimethylarginine dimethylaminohydrolase. Arterioscler. Thromb. Vasc. Biol. 23, 1455-1459; doi:10.1161/01. ATV.0000081742.92006.59

Adams D. J., Rusko J., Van Slooten G. (1993): Calcium signalling in vascular endothelial cells, Ca2+ entry and release. In: Ion Flux in Pulmonary Vascular Control. (Ed. E. K. Weir), pp. 259-275, Plenum Press, New York

Alderton W. K., Cooper C. E., Knowles R. G. (2001): Nitric oxide synthases: structure, function and inhibition. Biochem. J. 357, 593-615; doi:10.1042/0264-6021:3570593

Andersen K., Pedersen B. K. (2008): The role of inflammation in vascular insulin resistance with focus on IL-6. Horm. Metab. Res. 40, 635-639; doi:10.1055/s-0028-1083810

Anderson E. A., Mark A. L. (1989): Flow-mediated and reflex changes in large peripheral artery tone in humans. Circulation 79, 93-100

Andrews N. P., Prasad A., Quyyumi A. A. (2001): N-acetylcysteine improves coronary and peripheral vascular function. J. Am. Coll. Cardiol. 37, 117-123; doi:10.1016/S07351097(00)01093-7

Aversa A., Bruzziches R., Francomano D., Natali M., Gareri P., Spera G. (2009): Endothelial dysfunction and erectile dysfunction in the aging man. Int. J. Urol. 17, 38-47; doi:10.1111/j.1442-2042.2009.02426.x

Bakker W., Eringa E. C. Sipkema P., van Hinsbergh V. W. (2009): Endothelial dysfunction and diabetes: roles of hyperglycemia, impaired insulin signaling and obesity. Cell Tissue Res. 335, 165-189; doi:10.1007/s00441-008-0685-6 
Bauer P. M., Fulton D., Boo Y. C., Sorescu G. P., Kemp B. E., Jo H., Sessa W. C. (2003): Compensatory phosphorylation and protein-protein interactions revealed by loss of function and gain of function mutants of multiple serine phosphorylation sites in endothelial nitric-oxide synthase. J. Biol. Chem. 278, 14841-14849; doi:10.1074/ jbc.M211926200

Bauer V. (1993): NANC transmission in intestines and its pharmacological modulation. Acta Neurobiol. Exp. 53, 65-77

Bauer V., Gergel' D. (1994): Endothelium and reactive oxygen species. Bratisl. Med. J. 95, 243-263

Bauer V., Nakajima T., Pucovský V., Onoue H., Ito Y. (2000): Effects of superoxide generating systems on muscle tone, cholinergic and NANC responses in cat airways. J. Autonom. Ner. System 79, 34-44; doi:10.1016/S0165-1838(99)00100-9

Baynes J. W. (1991): Perspectives in diabetes. Role of oxidative stress in development of complications in diabetes. Diabetes 40, 405-412; doi:10.2337/diabetes.40.4.405

Beckman J. S., Koppenol W. H. (1996): Nitric oxide, superoxide, and peroxynitrite: the good, the bad, and ugly. Am. J. Physiol. 271, C1424-1437

Beny J. L., Burnet P. C. (1988): Neither nitric oxide nor nitroglycerin accounts for all the characteristics of endothelially mediated vasodilatation of pig coronary arteries. Blood Vessels 25, 308-311

Besler C., Doerries C., Giannotti G., Lüscher T. F., Landmesser U. (2008): Pharmacological approaches to improve endothelial repair mechanisms. Expert. Rev. Cardiovasc. Ther. 6, 1071-1082; doi:10.1586/14779072.6.8.1071

Blatter L. A., Wier W. G. (1994): Nitric oxide decreases (Ca2+)i in vascular smooth muscle by inhibition of the calcium current. Cell Calcium 15, 122-131; doi:10.1016/01434160(94)90051-5

Boeckstaens G. E., Bult H., Pelckmans P. A., Jordaens F. H., Hermen A. G., Marcke Y. M. (1990): Nitric oxide release in response to stimulation of nonadrenergic noncholinergic nerves. Arch. Int. Pharmacodyn. Ther. 305, 232-235

Booth A., Wallace S., McEniery C. M., Yasmin Brown J., Jayne D. R., Wilkinson I. B. (2004): Inflammation and arterial stiffness in systemic vasculitis: a model of vascular inflammation. Arthritis. Rheum. 50, 581-588; doi: $10.1002 /$ art. 20002

Bratt J. M., Franzi L. M., Linderholm A. L., O’Roark E. M., Kenyon N. J., Last J. A. (2009): Arginase inhibition in airways from normal and nitric oxide synthase 2-knockout mice exposed to ovalbumin. Toxicol. Appl. Pharmacol. 242, 1-8; doi:10.1016/j.taap.2009.09.018

Bredt D. S., Snyder S. H. (1990): Isolation of nitric oxide synthetase, a calmodulin requiring enzyme. Proc. Natl. Acad. Sci. USA 87, 682-685; doi:10.1073/pnas.87.2.682

Brouet A., Sonveaux P., Dessy C., Balligand J. L., Feron O. (2001): Hsp90 ensures the transition from the early Ca2+-dependent to the late phosphorylation-dependent activation of the endothelial nitric-oxide synthase in vascular endothelial growth factor-exposed endothelial cells. J. Biol. Chem. 276, 32663-32669; doi:10.1074/jbc.M101371200

Buga G. M., Ignarro L. J. (1992): Electrical field stimulation causes endothelium-dependent and nitric oxide-mediated relaxation of pulmonary artery. Amer. J. Physiol. 262, H973-979

Bulhak A. A., Jung C., Ostenson C. G., Lundberg J. O., Sjöquist P. O., Pernow J. (2009): PPAR-alpha activation protects the type 2 diabetic myocardium against ischemia-reperfusion injury: involvement of the PI3-Kinase/Akt and NO pathway. Am. J. Physiol. Heart. Circ. Physiol. 296, H719-727; doi:10.1152/ajpheart.00394.2008

Büsse R., Mülsch A. (1990): Calcium-dependent nitric oxide synthesis in endothelial cytosol is mediated by calmodulin. FEBS Lett. 256, 133-136; doi:10.1016/0014-5793(90)80902-U

Büsse R., Fichtner H., Luckhoff A., Kolehortckt M. (1988): Hyperpolarization and increased free calcium in acetylcholine- stimulated endothelial cells. Amer. J. Physiol. 255, H965-969

Cai H., Harrison D. G. (2000): Endothelial dysfunction in cardiovascular diseases: the role of oxidant stress. Circ. Res. 87, 840-844

Carden D. L., Granger D. N. (2000): Pathophysiology of ischaemia-reperfusion injury. J. Pathol. 190, 255266; doi:10.1002/(SICI)1096-9896(200002)190:3<255:: AID-PATH526>3.0.CO;2-6

Carr A., Frei B. (2000): The role of natural antioxidants in preserving the biological activity of endothelium-derived nitric oxide. Free Radic. Biol. Med. 28, 1806-1814; doi:10.1016/ S0891-5849(00)00225-2

Carvajal J. A., Germain A. M., Huidobro-Toro J. P., Weiner C. P. (2000): Molecular mechanism of cGMP-mediated smooth muscle relaxation. J. Cell Physiol. 184, 409-420; doi:10.1002/10974652(200009)184:3<409::AID-JCP16>3.0.CO;2-K

Chatterjee A., Catravas J. D. (2008): Endothelial nitric oxide (NO) and its pathophysiologic regulation. Vascul. Pharmacol. 49, 134-140; doi:10.1016/j.vph.2008.06.008

Chien W. Y., Yang K. D., Eng H. L., Hu Y. H., Lee P. Y., Wang S. T., Wang P. W. (2005): Increased plasma concentration of nitric oxide in type 2 diabetes but not in nondiabetic individuals with insulin resistance. Diabetes Metab. 31, 63-68; doi:10.1016/S1262-3636(07)70168-4

Chorianopoulos E., Bea F., Katus H. A., Frey N. (2009): The role of endothelial cell biology in endocarditis. Cell Tissue Res. 335, 153-163; doi:10.1007/s00441-008-0687-4

Cleland S. J., Sattar N., Petrie J. R., Forouhi N. G., Elliott H. L., Connell J. M. C. (2000): Endothelial dysfunction as a possible link between C-reactive protein levels and cardiovascular disease. Clin. Sci. (London) 98, 531-535; doi:10.1042/CS20000013

Collins P., Lewis M. J., Henderson A. H. (1988): Endotheliumderived factor relaxes vascular smooth muscle by cyclic GMP-mediated effects on calcium movements. In: Relaxing and Contracting Factors, Biological and Clinical Research (Eds. P. M. Vanhoutte, N. J. Clifton), pp. 267-283, Human Press, New York

Cooke J. P. (2005): ADMA: its role in vascular disease. Vasc. Med. 10, S1-2; doi:10.1191/1358863x05vm598oa

Cordes C. M., Bennett R. G., Siford G. L., Hamel F. G. (2009): Nitric oxide inhibits insulin-degrading enzyme activity and function through S-nitrosylation. Biochem. Pharmacol. 77, 1064-1073; doi:10.1016/j.bcp.2008.12.006 
Cryer A. (1998): Scale and diversity of interactions at the vascular endothelium. In: Biochemical Interactions at the Endothelium (Ed. D. G.), pp. 1-3, Pergamon Press, Oxford

Darley-Usmar V., Halliwell B. (1996): Blood Radicals. Reactive nitrogen species, reactive oxygen species, transition metal ions, and the vascular system. Pharmaceut. Res. 13, 649-662; doi:10.1023/A:1016079012214

Davies M. G., Hagen P. O. (1993): The vascular endothelium. A new horizon. Ann. Surg. 218, 593-609; doi:10.1097/00000658199321850-00003

De Jager J., Dekker J. M., Kooy A., Kostense P. J., Nijpels G., Heine R. J., Bouter L. M., Stehouwer C. D. (2006): Endothelial dysfunction and low-grade inflammation explain much of the excess cardiovascular mortality in individuals with type 2 diabetes: the hoorn study. Arterioscler. Thromb. Vasc. Biol. 26, 1086-1093; doi:10.1161/01. ATV.0000215951.36219.a4

DeMey J. G., Vanhoutte P. M. (1983): Anoxia and endothelium dependent reactivity in canine femoral artery. J. Physiol. (London) 335, 65-74

De Vriese A. S., Verbeuren T. J., van de Voorde J., Lameire N. H., Vanhoutte P. M. (2000): Endothelial dysfunction in diabetes. Br. J. Pharmacol. 130, 963-974; doi:10.1038/ sj.bjp.0703393

Di Corleto P. E., Chisalm G. M. (1986): Participation of the endothelium in the development of the atherosclerotic plaque. Prog. Lipid. Res. 25, 365-374, doi:10.1016/01637827(86)90074-3

Dimmeler S., Fleming I., Fisslthaler B., Hermann C., Busse R., Zeiher A. M. (1999): Activation of nitric oxide synthase in endothelial cells by Akt-dependent phosphorylation. Nature 399, 601-605; doi:10.1038/21224

Duffy S. J., Gokce N., Holbrook M., Hunter L. M., Biegelsen E. S., Huang A., Keaney J. F., Vita J. A. (2001): Effect of ascorbic acid treatment on conduit vessel endothelial dysfunction in patients with hypertension. Am. J. Physiol. Heart Circ. Physiol. 280, H528-534

Duprez D. A., Somasundaram P. E., Sigurdsson G., Hoke L., Florea N., Cohn J. N. (2005): Relationship between C-reactive protein and arterial stiffness in an asymptomatic population. J. Hum. Hypertens. 19, 515-519; doi:10.1038/ sj.jhh. 1001860

Ebrahimian T., Mathieu E., Silvestre J. S., Boulanger C. M. (2003): Intraluminal pressure increases vascular neuronal nitric oxide synthase expression. J. Hypertens. 21, 937-942; doi:10.1097/00004872-200305000-00018

Eisenberg P. R. (1991): Endothelial cell mediators of thrombosis and fibrinolysis: review in depth. Coronary Artery Dis. 2, 129-166; doi:10.1097/00019501-199104000-00001

Elliott D. (2008): Migraine and stroke: current perspectives. Neurol. Res. 30, 801-812; doi:10.1179/174313208X341049

Elliot S. J., Meszaros G. J., Schilling M. (1992): Effect of oxidant stress on calcium signaling in vascular endothelial cells. Free Rad. Biol. Med. 13, 635-650; doi:10.1016/08915849(92)90038-I

Esterbauer H., Rotleneder M., Striegl G. (1989): Vitamin E and other lipophilic antioxidants protect LDL against oxidation. Fat. Sci. Technol. 91, 316-324
Evcimen D. N., King G. L. (2007): The role of protein kinase $\mathrm{C}$ activation and the vascular complications of diabetes. Pharmacol. Res. 55, 498 -510; doi:10.1016/ j.phrs.2007.04.016

Félétou M., Köhler R., Vanhoutte P.M. (2010): Endothelium-derived vasoactive factors and hypertension: possible roles in pathogenesis and as treatment targets. Curr. Hypertens. Rep. 12, 267-275; doi:10.1007/s11906-010-0118-2

Feron O., Belhassen L., Kobzik L., Smith T. W., Kelly R. A., Michel T. (1996): Endothelial nitric oxide synthase targeting to caveolae. Specific interactions with caveolin isoforms in cardiac myocytes and endothelial cells. J. Biol. Chem. 271, 22810-22814; doi:10.1074/jbc.271.37.22810

Ferrario C. M. (1993): Biological roles of angiotensin-(1-7). Hypertension Res. 72, 239-245

Fichtlscherer S., Rossig L., Breuer S., Vasa M., Dimmeler S., Zeiher A. M. (2001): Tumor necrosis factor antagonism with etanercept improves systemic endothelial vasoreactivity in patients with advanced heart failure. Circulation 104, 3023-3025; doi:10.1161/hc5001.101749

Florey L. (1966): The endothelial cell. Brit. Med. J. (Clin. Res.) 2, $487-490$

Fowler M. J. (2008): Microvascular and macrovascular complications of diabetes. Clin. Diab. 26, 77-82; doi:10.2337/diaclin.26.2.77

Fontana J., Fulton D., Chen Y., Fairchild T. A., McCabe T. J., Fujita N., Tsuruo T., Sessa W. C. (2002): Domain mapping studies reveal that the $\mathrm{M}$ domain of hsp90 serves as a molecular scaffold to regulate Akt-dependent phosphorylation of endothelial nitric oxide synthase and NO release. Circ. Res. 90, 866-873; doi:10.1161/01. RES.0000016837.26733.BE

Forstermann U., Mulsch A., Bohme E., Busse R. (1986): Stimulation of soluble guanylate cyclase by an acetylcholine-induced endothelium-derived factor from rabbit and canine arteries. Circ. Res. 58, 531-538

Funk D. J., Parrillo J. E., Kumar A. (2009): Sepsis and septic shock: a history. Crit. Care Clin. 25, 83-101; doi:10.1016/ j.ccc.2008.12.003

Fujiki T., Shimokawa H., Morikawa K., Kubota H., Hatanaka M., Talukder M. A. H., Matoba T., Takeshita A., Sunagawa K. (2005): Endothelium-derived hydrogen peroxide accounts for the enhancing effect of an angiotensinconverting enzyme inhibitor on endothelium-derived hyperpolarizing factor-mediated responses in mice. Arterioscl. Thromb. Vasc. Biol. 25, 766-771; doi:10.1161/01. ATV.0000158498.19027.75

Fulton D., Gratton J. P., Sessa W. C. (2001): Post-translational control of endothelial nitric oxide synthase: why isn't calcium/calmodulin enough? J. Pharmacol. Exp. Ther. 299, 818-824

Fulton D., Gratton J. P., McCabe T. J., Fontana J., Fujio Y., Walsh K., Franke T. F., Papapetropoulos A., Sessa W. C. (1999): Regulation of endothelium-derived nitric oxide production by the protein kinase Akt. Nature 399, 597-601; doi: $10.1038 / 21218$

Furchgott R. F. (1988): Studies on relaxation of rabbit aorta by sodium nitrite the basis for the proposal that acid-activatible 
inhibitory factor from bovine retractor penis is inorganic nitrite and the endothelium-derived relaxing factor is nitric oxide. In: Vasodilatation (Ed. P. M. Vanhoutte), pp. 401-412, Raven Press, New York

Furchgott R. F., Vanhoutte P. M. (1989): Endothelium-derived relaxing and contracting factors. FASEB J. 3, 2007-2018

Furchgott R. F., Zawadski J. V. (1980): The obligatory role of endothelial cells in the relaxation of arterial smooth muscle by acetylcholine. Nature (London) 288, 373-376; doi:10.1038/288373a0

Garcia-Cardena G., Oh P., Liu J., Schnitzer J. E., Sessa W. C. (1996): Targeting of nitric oxide synthase to endothelial cell caveolae via palmitoylation: implications for nitric oxide signaling. Proc. Natl. Acad. Sci. U. S. A. 93, 6448-6453; doi:10.1073/pnas.93.13.6448

Garthwaite J., Charles J. L., Chess-Williams R. (1988): Endothelium-derived relaxing factor release on activation of NMDA receptors suggests release intracellular messenger in the brain. Nature 336, 385-388; do$\mathrm{i}: 10.1038 / 336385 \mathrm{a} 0$

Getz G. S. (1993): Report on the workshop on diabetes and mechanism of atherogenesis. Arterioscler. Thromb. 13, 459-464

Ghiadoni L., Mosca M., Tani C., Virdis A., Taddei S., Bombardieri S. (2008): Clinical and methodological aspects of endothelial function in patients with systemic autoimmune diseases. Clin. Exp. Rheumatol. 26, 680-687

Ginnan R., Guikema B. J., Halligan K. E., Singer H. A., Jourd'heuil D. (2008): Regulation of smooth muscle by inducible nitric oxide synthase and NADPH oxidase in vascular proliferative diseases. Free Radic. Biol. Med. 44, 1232-1245; doi:10.1016/j.freeradbiomed.2007.12.025

Girard P., Potier P. (1993): NO, thiols and disulfides. FEBS Lett. 320, 7-8; doi:10.1016/0014-5793(93)81645-G

Glovind J. S., Hartman J., Clemmensen K. E., Jessen K. E., Dan S. (1992): Studies of the role of lipoproteins in human pathology. Arch. Path. Microbiol. Scand. 30, 1-6; doi:10.1111/j.1699-0463.1952.tb00157.x

Godfraind T. Egleme C., Osachie I. A. (1985): Role of endothelium in the contractile response of rat aorta alfa-adrenoceptor agonists. Clin. Sci. 68, S65-71

Gold M. E., Wood K. S., Buga G. M., Byrus R. E., Ignarro L. J. (1989): L-arginine causes whereas L-arginine succinic acid inhibits endothelium dependent vascular smooth muscle relaxation. Biochem. Biophys. Res. Commun. 161, 536-543; doi:10.1016/0006-291X(89)92632-6

Gonzalez-Juanatey C., Llorca J., Miranda-Filloy J. A., Amigo-Diaz E., Testa A., Garcia-Porrua C., Martin J., Gonzalez-Gay M. A. (2007): Endothelial dysfunction in psoriatic arthritis patients without clinically evident cardiovascular disease or classic atherosclerosis risk factors. Arthritis Rheum. 57, 287-293; doi:10.1002/art.22530

Gorbe A., Giricz Z., Szunyog A., Csont T., Burley D. S., Baxter G. F., Ferdinandy P. (2010): Role of cGMP-PKG signaling in the protection of neonatal rat cardiac myocytes subjected to simulated ischemia/reoxygenation. Basic Res. Cardiol. 105, 643-650; doi:10.1007/s00395-0100097-0
Govers R., Rabelink T. J. (2001): Cellular regulation of endothelial nitric oxide synthase. Am. J. Physiol. Renal Physiol. 280, F193-206

Granger D. N. (1988): Role of xanthine oxidase and granulocytes in ischemia-reperfusion injury. Am. J. Physiol. 255, H1269-1275

Granger D. N. (1999): Ischemia-reperfusion: mechanisms of microvascular dysfunction and the influence of risk factors for cardiovascular disease. Microcirculation 6, 167-178

Gratton J. P., Fontana J., O’Connor D. S., Garcia-Cardena G., McCabe T. J., Sessa W. C. (2000): Reconstitution of an endothelial nitric-oxide synthase (eNOS), hsp90 and caveolin-1 complex in vitro. Evidence that hsp90 facilitates calmodulin stimulated displacement of eNOS from caveolin-1. J. Biol. Chem. 275, 22268-22272; doi:10.1074/jbc.M001644200

Grisham M. B., Granger D. N., Lefer D. L. (1998): Modulation of leukocyte-endothelial interactions by reactive metabolites of oxygen and nitrogen: relevance to ischemic heart disease. Free Rad. Biol. 25, 404-433; doi:10.1016/S08915849(98)00094-X

Gryglewski R. J., Palmer R. M. J., Moncada S. (1986): Superoxide anion is involved in the breakdown of endotheliumderived vascular relaxing factor. Nature 320, 454-456; doi:10.1038/320454a0

Gutterman D. D. (2002): Vascular dysfunction in hypertriglycemia. Is protein kinase $\mathrm{C}$ the culprit? Circ. Res. 90, 5-7

Hamilton S. J., Chew G. T., Watts G. F. (2007): Therapeutic regulation of endothelial dysfunction in type 2 diabetes mellitus. Diabetes Vasc. Dis. Res. 4, 89-102; doi:10.3132/ dvdr.2007.026

Hansel S., Lassig G., Pistrosch F., Passauer J. (2003): Endothelial dysfunction in young patients with long-term rheumatoid arthritis and low disease activity. Atherosclerosis 170, 177-180; doi:10.1016/S0021-9150(03)00281-8

Harrison D. G., Widder J., Grumbach I., Chen W., Weber M., Searles C. (2006): Endothelial mechanotransduction, nitric oxide and vascular inflammation. J. Internal Med. 259, 351-363; doi:10.1111/j.1365-2796.2006.01621.x

Heistad D. D. (2008): Endothelial function in the time of the giants. J. Cardiovasc. Pharmacol. 52, 385-392; doi:10.1097/ FJC.0b013e31818a403b

Heitzer T., Yla-Herttuala S., Luoma J., Kurz S., Munzel T., Just H., Olschewski M., Drexler H. (1996): Cigarette smoking potentiates endothelial dysfunction of forearm resistance vessels in patients with hypercholesterolemia. Role of oxidized LDL. Circulation 93, 1346-1353

Hennig B., Chow C. K. (1988): Lipid peroxidation and endothelial cell injury implications in atherosclerosis. Free Rad. Biol. Med. 4, 99-106; doi:10.1016/0891-5849(88)90070-6

Henry Y., Lepoivre M., Drapier J. C., Ducrocq C., Boucher J. L., Guissani A. (1993): EPR characterization of molecular targets for NO in mammalian cells and organelles. FASEB J. 7, 1124-1134.

Hingorani A. D., Cross J., Kharbanda R. K., Mullen M. J., Bhagat K., Taylor M., Donald A. E., Palacios M., Griffin G. E., Deanfield J. E., MacAllister R. J., Vallance P. (2000): Acute systemic inflammation impairs endothelium-dependent dilatation in humans. Circulation 102, 994-999 
Hogan J. C., Lewis M. J., Hunderson A. H. (1988): In vivo EDRF activity influences platelet function. Brit. J. Pharmacol. 94, 1020-1022

Huang A., Sun D., Shesely E.G., Levee E.M., Koller A., Kaley G. (2002): Neuronal NOS-dependent dilation to flow in coronary arteries of male eNOS-KO mice. Am. J. Physiol. Heart Circ. Physiol. 282, H429-436

Hunt J. V., Smith C. T., Wolf S. P. (1990): Autoxidative glycosylation and possible involvement of peroxides and free radicals in LDL modification by glucose. Diabetes 39, 1420-1424; doi:10.2337/diabetes.39.11.1420

Hurlimann D., Forster A., Noll G., Enseleit F., Chenevard R., Distler O., Bechir M., Spieker L. E., Neidhar M., Michel B. A., Gay R. E., Luscher T. F., Gay S., Ruschitzka F. (2002): Anti-tumor necrosis factor-alpha treatment improves endothelial function in patients with rheumatoid arthritis. Circulation 106, 2184-2187; doi:10.1161/01. CIR.0000037521.71373.44

Ignarro L. J. (1990a): Biosynthesis and metabolism of endotheliumderived nitric oxide. Annu Rev. Pharmacol. Toxicol. 30, 535-560; doi:10.1146/annurev.pa.30.040190.002535

Ignarro L. J. (1990b): Nitric oxide. A novel signal transduction mechanism for transcellular communication. Hypertension 16, 477- 483

Ignarro L. J. (2000): The unique role of nitric oxide as a signaling molecule in the cardiovascular system. Ital. Heart J. 1 (Suppl. 3), S28-29

Ignarro L. J., Byrus R. E., Buga G. M., Wood K. S. (1987): Endothelium-derived relaxing factor from pulmonary artery and vein possesses pharmacological and chemical properties identical to those of nitric oxide radical. Circ. Res. 61, 866-879

Ignarro L. J., Byrns R. E., Wood K. S. (1988): Biochemical and pharmacological properties of endothelium-derived relaxing factor and its similarity to nitric oxide Radical. In: Vasodilatation (Ed. P. M. Vanhoutte), pp. 427-435, Raven Press, New York

Jiang Z. Y., Lin Y. W., Clemont A., Feener E. P., Hein K. D., Igarashi M., Yamauchi T., White M. F., King G. L. (1999): Characterization of selective resistance to insulin signaling in the vasculature of obese Zucker (fa/fa) rats. J. Clin. Invest. 104, 447-457; doi:10.1172/JCI5971

Johansson C. C., Mougiakakos D., Trocme E., All-Ericsson C., Economou M. A., Larsson O., Seregard S., Kiessling R. (2010): Expression and prognostic significance of iNOS in uveal melanoma. Int. J. Cancer 126, 2682-2689

Johns A., Lategan T. W., Lodge N. J., Ryan U. S., van Breemen C., Adams D. J. (1987): Calcium entry through receptor operated channels in bovine pulmonary artery endothelial cells. Tissue Cell 19, 733-745; doi:10.1016/00408166(87)90015-2

Johns R. A., Linden J. M., Peach M. J. (1989): Endothelium-dependent relaxation and cyclic GMP accumulation in rabbit pulmonary artery are selectively impaired by moderate hypoxia. Circ. Res. 65, 1508-1515

Kaibori M., Sakitani K., Oda M., Kamiyama Y., Masu Y., Okumura T. (1999): Immunosuppressant FK56 inhibits iNOS gene expression at a step of NF-Kappa B activation in rat he- patocytes. J. Hepatol. 30, 1138-1145; doi:10.1016/S01688278(99)80270-0

Kanner J., Harel S., Grant R. (1991): Nitric oxide as an antioxidant. Arch. Biochem. Biophys. 289, 130-136; doi:10.1016/00039861(91)90452-O

Katušic Z. S., d'Uscio L.V., Nath K. A. (2008): Vascular protection by tetrahydrobiopterin: progress and therapeutic prospects. TIPS 30, 48-54

Katušic Z. S., Vanhoutte P. M. (1986): Anoxic contraction in isolated cerebral arteries. Contribution of endotheliumderived factors, metabolites of arachidonic acid and calcium entry. J. Cardiovasc. Pharmacol. 8 (Suppl. 8), S97-101; doi:10.1097/00005344-198600088-00020

Katušic Z. S., Vanhoutte P. M. (1989): Superoxide anion is an endothelium derived contracting factor. Amer. J. Physiol. 257, H33-37

Khanna A., Cowled P. A, Fitridge R. A. (2005): Nitric oxide and skeletal muscle reperfusion injury: Current controversies. J. Surg. Res. 128, 98-107

Kibbe M., Billiar T., Tzeng E. (1999): Inducible nitric oxide synthase and vascular injury. Cardiovasc. Res. 43, 650-657; doi:10.1016/S0008-6363(99)00130-3

Kim J., Montagnani M., Koh K. K., Quon M. J. (2006): Reciprocal relationships between insulin resistance and endothelial dysfunction: molecular and pathophysiological mechanisms. Circulation 113, 1888-1904; doi:10.1161/CIRCULATIONAHA.105.563213

Korthuis R. J., Gute D. C., Cepinska G., Kvietys P. R. (1998): Cellular mechanisms of acute versus delayed preconditioning. Pathophysiology 5, 35-48; doi:10.1016/S0928-4680(98)00007-8

Lamas S., Marsden P. A., Li G. K., Tempst P., Michel T. (1992): Endothelial nitric oxide synthase: molecular cloning and characterization of a distinct constitutive enzyme isoform. Proc. Natl. Acad. Sci. U. S. A. 89, 6348-6352; doi:10.1073/pnas.89.14.6348

Lambert T. L., Kent R. S., Whorton A. R. (1986): Bradykinin stimulation of inositol polyphosphat production in porcine aortic endothelial cells. J. Biol. Chem. 261, 15288-15293

Lanas A. (2008): Role of nitric oxide in the gastrointestinal tract. Arthritis Res. Ther. 10 (Suppl. 2), 4-8; doi:10.1186/ar2465

Lefebvre R. A. (1995): Nitric oxide in the peripheral nervous system. Ann. Med. 27, 379-388; doi:10.3109/ 07853899509002591

Leloup C., Tourrel-Cuzin C., Magnan Ch., Karaca M., Castel J., Carneiro L., Colombani A. L., Ktorza A., Casteilla L., Pénicaud L. (2009): Mitochondrial reactive oxygen species are obligatory signals for glucose-induced insulin secretion. Diabetes 58, 673-681; doi:10.2337/db07-1056

Leung F. P., Yung L. M., Laher I., Yao X., Chen Z. Y., Huang Y. (2008): Exercise, vascular wall and cardiovascular diseases: an update (Part 1). Sports Med. 38, 1009-1024; doi:10.2165/00007256-200838120-00005

Leuris M. J., Hendersen A. H. (1987): A phorbolester inhibits the release of endothelium-derived relaxing factor. Eur. J. Pharmacol. 137, 167-171; doi:10.1016/00142999(87)90218-4

Loesch A., Burnstock G. (1998): Perivascular nerve fibres and endothelial cells of the rat basilar artery: immuno-gold 
labelling of antigenic sites for type I and type III nitric oxide synthase. J. Neurocytol. 27, 197-204; doi:10.1023/ A:1026493425977

Long C. J., Stone T. W. (1985): The release of endothelium derived relaxing factor is calcium dependent. Blood Vessels 22, 205-208

Loscalzo J., Vita J. A. (2000): Nitric oxide and the cardiovascular system. Humana Press, Totowa, New Jersey; doi:10.1385/ 1592590020

Lowenstein C. J., Dinerman J. L., Snyder S. H. (1994): Nitric oxide: a physiologic messenger. Annals Internal Med. 120, 227-237

Luo Z., Fujio Y., Kureishi Y., Rudic R. D., Daumerie G., Fulton D., Sessa W. C., Walsh K . (2000): Acute modulation of endothelial Akt/PKB activity alters nitric oxide-dependent vasomotor activity in vivo. J. Clin. Invest. 106, 493-499; doi:10.1172/JCI9419

Lüscher T. F. (1988): Pathophysiology of the vascular endotheliumhypertension. In: Endothelial Vasoactive Substances and Cardiovascular Disease (Ed. T. F. Lüscher), pp. 51-80, Karger, Sydney

Lüscher T. F. (1991): Endothelium-derived nitric oxide: the endogenous nitrovasodilator in the human cardiovascular system. Eur. Heart. J. 12 (Suppl. E), 2-11

Lüscher T. F., Baulanger Ch. M., Dali Y., Yang L. Ch. (1992): Endothelium-derived contracting factors. Hypertension 19, 117-130

Mackenzie I. S., Rutherford D., Mac Donald T. M. (2008): Nitric oxide and cardiovascular effects: new insights in the role of nitric oxide for the management of osteoarthritis. Arthritis Res. Ther. 10 (Suppl. 2), 3-14; doi:10.1186/ar2464

Makimattila S., Virkamaki A., Groop P. H., Cockcroft J., Utriainen T., Fagerudd J., Yki-Jarvinen H. (1996): Chronic hyperglycemia impairs endothelial function and insulin sensitivity via different mechanisms in insulin-dependent diabetes mellitus. Circulation 94, 1276-1282

Maslov L. N., Kolar F., Barzakh E. I. (2009): Signaling mechanism of NO-induced increase in cardiac tolerance to ischemiareperfusion. Ross. Fiziol. Zh. Im. I. M. Sechenova 95, 1175-1189 (in Russian)

Matsunaga T., Nakajima T., Miyazaki T., Koyama I., Hokari S., Inoue I., Kawai S., Shimomura H., Katayama S., Hara A., Komoda T. (2003): Glycated high-density lipoprotein regulates reactive oxygen species and reactive nitrogen species in endothelial cells. Metabolism 52, 42-49; doi: $10.1053 /$ meta.2003.50013

McEniery Yasmin C. M., Wallace S., Mackenzie I. S., Cockcroft J. R., Wilkinson I. B. (2004): C-reactive protein is associated with arterial stiffness in apparently healthy individuals. Arterioscler. Thromb. Vasc. Biol. 24, 969-974; doi:10.1161/01.ATV.zhq0504.0173

Menardi A. C., Viaro F., Vicente W. V., Rodrigues A. J., Evora P. R. (2006): Hemodynamic and vascular endothelium function studies in healthy pigs after intravenous bolus infusion of methylene blue. Arq. Bras. Cardiol. 87, 525-532

Mendelsohn M. E., Loscalzo J. (1992): The endotheliopathies. In: Vascular Medicine. 1st. ed. (Eds. J. Loscalzo, M. Creagher, V. J. Dzau), pp. 251-278, Little Brown, Boston
Miller D., Forrester K., Hart D. A., Leonard C., Salo P., Bray R. C. (2007): Endothelial dysfunction and decreased vascular responsiveness in the anterior cruciate ligament-deficient model of osteoarthritis. J. Appl. Physiol. 102, 1161-1169; doi:10.1152/japplphysiol.00209.2006

Moncada S., Palmer R. M. J., Higgs E. A. (1989): Biosynthesis of nitric oxide from L-arginine: a pathway for the regulation of cell function and communication. Biochem. Pharmacol. 38, 1709-1715; doi:10.1016/0006-2952(89)90403-6

Moncada S., Palmer R. M. J., Higgs, E. A. (1991): Nitric oxide: physiology, pathophysiology, and pharmacology. Pharmacol. Rev. 43, 109-142

Mugge A., Forsterman U., Lichtlen P. R. (1989): Endothelial functions in cardiovascular diseases. Z. Kardiol. 78, 147-160 (in German)

Muijsers R. B. R., Folkerts G., Henricks P. A. J., Sadeghi-Hashjin G., Nijkamp F. P. (1997): Peroxynitrite: a two-faced metabolite of nitric oxide. Life Sci. 60, 1833-1845; doi:10.1016/S0024-3205(96)00651-0

Murad F., Mittal C. K., Arnold W. P., Katsuki S., Kimura H. (1978): Guanylate cyclase: activation by azide, nitro compounds, nitric oxide, and hydroxyl radical and inhibition by hemoglobin and myoglobin. Adv. Cyclic Nucleotide Res. 9, 145-158

Muscogiuri G., Chavez A. O., Gastaldelli A., Perego L., Tripathy D., Saad M. J., Velloso L., Folli F. (2008): The crosstalk between insulin and renin-angiotensin-aldosterone signaling systems and its effect on glucose metabolism and diabetes prevention. Curr. Vasc. Pharmacol. 6, 301-312; doi:10.2174/157016108785909715

Mülsch A., Mordvintcev P., Vanin A., Büsse R. (1993): Formation and release of dinitrosyl iron complexes by endothelial cells. Biochem. Biophys. Res. Commun. 196, 1303-1308; doi:10.1006/bbrc.1993.2394

Münzel T. (2008): Endothelial dysfunction: pathophysiology, diagnosis and prognosis. Dtsch. Med. Wochenschr. 133, 2465-2470 (in German); doi:10.1055/s-00281100941

Myers P. R., Minor R. L., Guerra R. Jr., Bates J. N., Harrison D. G. (1990): Vasorelaxant properties of the endotheliumderived relaxing factor more closely resemble S-nitrosocysteine than nitric oxide. Nature 345, 161-163; doi:10.1038/345161a0

Nakashidze I. M. (2009): The changes of content of TNF-alpha, nitric oxide and FeS-NO in patients blood with traumatic shock under Plaferon LB influence. Georgian Med. News. 171, 76-78 (in Russian)

Nathanson D., Nyström T. (2009): Hypoglycemic pharmacological treatment of type 2 diabetes: targeting the endothelium. Mol. Cell. Endocrinol. 297, 112-126; doi:10.1016/ j.mce.2008.11.016

Neary P., Redmond H. P. (1999): Ischaemia-reperfusion injury and the systemic inflammatory response syndrome. In: Ischemia-Reperfusion Injury (Eds. P. A. Grace, R. T. Mathie), pp. 123-136, Blackwell Science, London

Noack E., Feelisch M. (1989): Molecular aspects underlying the vasodilator action of molsidomin. J. Cardiovasc. Pharmacol. 14, S1-5; doi:10.1097/00005344-198906152-00002 
Nosálová V., Navarová J., Mihalová D., Sotníková R. (2007): Mesenteric ischemia/reperfusion-induced intestinal and vascular damage: effect of stobadine. Meth. Find. Exp. Clin. Pharmacol. 29, 39-45; doi:10.1358/mf.2007.29.1.1063495

Oess S., Icking A., Fulton D., Govers R., Muller-Esterl W. (2006): Subcellular targeting and trafficking of nitric oxide synthases. Biochem. J. 396, 401-409; doi:10.1042/ BJ20060321

Pacher P., Beckman J. S., Liaudet L. (2007): Nitric oxide and peroxynitrite in health and disease. Physiol. Rev. 87, 315-424; doi:10.1152/physrev.00029.2006

Pacher P., Szabo C. (2008): Role of the peroxynitrite-poly (ADPribose) polymerase pathway in human disease. Am. J. Pathol. 173, 2-13; doi:10.2353/ajpath.2008.080019

Palinski W., Rosenfeld M. E., Yla-Hertuala S., Gurtner G. C., Socher S. S., Butler S. W., Parthasarathy S., Carew T. E., Steinberg D., Witztum J. L. (1989): Low density lipoprotein undergoes oxidative modification in vivo. Proc. Natl. Acad. Sci. U.S.A. 86, 1371-1375; doi:10.1073/pnas.86.4.1372

Palmer R. M. J., Ashton D. S., Moncada S. (1988): Vascular endothelial cells synthetises nitric oxide from L-arginine. Nature 333, 664-666; doi:10.1038/333664a 0

Palmer R. M. J., Ferrige A. G., Moncada S. (1987): Nitric oxide release accounts for the biological activity of edothelium-derived relaxing factor. Nature 327, 524-526; doi: $10.1038 / 327524 \mathrm{a} 0$

Parratt J. R. (1998): Nitric oxide in sepsis and endotoxemia. J. Antimicrobial Chemotherapy 41 (Suppl. A), 31-39; doi:10.1093/jac/41.suppl_1.31

Pasceri V., Willerson J. T., Yeh E. T. (2000): Direct proinflammatory effect of C-reactive protein on human endothelial cells. Circulation 102, 2165-2168

Patil C. S., Singh V. P., Kulkarni S. K. (2006): Modulatory effect of sildenafil in diabetes and electroconvulsive shockinduced cognitive dysfunction in rats. Pharmacol. Rep. 58, 373-380

Peinado V. I., Pizarro-S., Barberà J. A. (2008): Pulmonary vascular involvement in COPD. Chest 134, 808-814; doi:10.1378/ chest.08-0820

Pieper G. M., Gross G. R. (1991): Endothelial dysfunction in diabetes. In: Cardiovascular Significance of EndotheliumDerived Vasoactive Factors. 1st. ed. (Ed. G. M. Rubanyi), pp. 223-249, Futura, Mount Kisco, New York

Piper M. K., Raza K., Nuttall S. L., Stevens R., Toescu V., Heaton S., Gardner-Medwin J., Hiller L., Martin U., Townend J., Bacon P.A., Gordon C. (2007): Impaired endothelial function in systemic lupus erythematosus. Lupus 16, 84-88; doi: $10.1177 / 0961203306074842$

Piotrowski J. J., Hunter G. C., Eskelson C. D., Dubick M. A., Berhard V. M. (1990): Evidence for lipid peroxidation in atherosclerosis. Life Sci. 46, 715-721; doi:10.1016/00243205(90)90077-5

Potenza M. A., Gagliardi S., Nacci C., Carratu M. R., Montagnani M. (2009): Endothelial dysfunction in diabetes: from mechanisms to therapeutic targets. Curr. Med. Chem. 16, 94-112; doi:10.2174/092986709787002853

Potenza M. A., Montagnani M. (2008): Abnormal insulin signaling: early detection of silent coronary artery disease- erectile dysfunction? Curr. Pharm. Des. 14, 3737-3748; doi:10.2174/138161208786898707

Prasad A., Andrews N. P., Padder F. A., Husain M., Quyyumi A. A. (1999): Glutathione reverses endothelial dysfunction and improves nitric oxide bioavailability. J. Am. Coll. Cardiol. 34, 507-514; doi:10.1016/S0735-1097(99)00216-8

Radomski M. C., Palmer R. M. J., Moncada S. (1987): Comparative pharmacology of endothelium derived relaxing factor, nitric oxide and prostacyclin in platelets. Brit. J. Pharmacol. 92, 181-187

Raitakari O. T., Adams M. R., McCredie R. J., Griffiths K. A., Stocker R., Celermajer D. S. (2000): Oral vitamin C and endothelial function in smokers: short-term improvement, but no sustained beneficial effect. J. Am. Coll. Cardiol. 35, 1616-1621; doi:10.1016/S0735-1097(00)00576-3

Rappoport R. M., Murad F. (1983): Agonist-induced endotheliumdependent relaxation in rat thoracic aorta may be mediated through cGMP. Circ. Res. 52, 352-357

Rappoport R. M., Draznin M. B., Murad F. (1983): Endothelium-dependent relaxation in rat aorta may be mediated through cyclic GMP-dependent protein phosphorylation. Nature 306, 174-176; doi:10.1038/306174a0

Redington A. E. (2006): Modulation of nitric oxide pathways: therapeutic potential in asthma and chronic obstructive pulmonary disease. Eur. J. Pharmacol. 533, 263-276; doi:10.1016/j.ejphar.2005.12.069

Rembold Ch. M. (1992): Regulation of contraction and relaxation in arterial smooth muscle. Hypertension 20, 129-137

Ress D. D., Palmer R. M. J., Hodson H. F., Moncada S. (1989): A specific inhibitor of nitric oxide formation from L-arginine attenuates endothelium-dependent relaxation. Brit. J. Pharmacol. 96, 418-424

Roks A. J. M. (2002): Improvement of endothelium-derived hyperpolarizing factor function by renin-angiotensin system inhibition: paving the way towards prevention of age-related endothelial dysfunction. J. Hypertension 20, 363-365; doi:10.1097/00004872-200203000-00005

Ross R. (1993): The pathogenesis of atherosclerosis: a perspective for the 1990s. Nature 362, 801-809; doi:10.1038/362801a0

Ross R. (1999): Atherosclerosis: an inflammatory disease. N. Engl. J. Med. 340, 115-126; doi:10.1056/NEJM199901143400207

Rubanyi G. M. (1988): Vascular effect of oxygen-derived free radicals. Free Rad. Biol. Med. 4, 107-120; doi:10.1016/08915849(88)90071-8

Rubanyi G. M. (1991a): Endothelium derived relaxing and contracting factors. J. Cell Biochem. 46, 27-36; doi:10.1002/ jcb. 240460106

Rubanyi G. M. (1991b): Cardiovascular significance of endothelium-derived vasoactive factors. Futura, Mount Kisco, New York

Rubanyi G. M., Johns A., Harrison D. G., Wilcox D. (1989): Evidence that EDRF may be identical with an 5-nitrothiol and not with free nitric oxide. Circulation 80 (Suppl. 2), 276-281

Rubanyi G. M., Ho E., Canta E. H., Lumma W. C., Botello L. H. P. (1991): Cytoprotective function of nitric oxide. Inactivation of superoxide radicals produced by human 
leukocytes. Biophys. Res. Commun. 181, 1392-1397; doi:10.1016/0006-291X(91)92093-Y

Rubanyi G. M., Vanhoutte P. M. (1985): Hypoxia releases a vasoconstrictor substance from the canine vascular endothelium. J. Physiol. (London) 364, 45-56

Rubanyi G. M., Vanhoutte P. M. (1986a): Oxygen-derived free radicals, endothelium, and responsiveness of vascular smooth muscle. Amer. J. Physiol. 250, H815-821

Rubanyi G. M., Vanhoutte P. M. (1986b): Superoxide anion and hypoxia inactivate endothelium derived relaxing factor. Amer. J. Physiol. 250, H822-827

Rumley A. G., Woodward M., Rumley A., Rumley J., Lowe G. D. (2004): Plasma lipid peroxides: relationships to cardiovascular risk factors and prevalent cardiovascular disease. Q. J. Med. 97, 809-816

Ryan U. S. (1989): Endothelium as transducing surface. J. Mol. Cell Cardiol. 21 (Suppl. 1), 85-90; doi:10.1016/00222828(89)90841-9

Sanders D. B, Kelley T., Larson D. (2000): The role of nitric oxide synthase/nitric oxide in vascular smooth muscle control. Perfusion 15, 97-104

Sari I., Okan T., Akar S., Cece H., Altay C., Secil M., Birlik M., Onen F., Akkoc N. (2006): Impaired endothelial function in patients with ankylosing spondylitis. Rheumatology $(\mathrm{Ox}-$ ford) 45, 283-286; doi:10.1093/rheumatology/kei145

Schmidt K., Greier W. F., Kostner G. M., Mayer B., Bohme E., Kukovetz W. R. (1992): Stimulation of soluble guanylate cyclase by endothelium-derived relaxing factor is antagonized by oxidized low density lipoprotein. J. Cardiovasc. Pharmacol. 17 (Suppl. 3), S83-88; doi:10.1097/00005344199117003-00015

Schödela J., Padmapriyaa P., Marxb A., Huangc P. L., Ertl G., Kuhlencordt P. J. (2009): Expression of neuronal nitric oxide synthase splice variants in atherosclerotic plaques of apoE knockout mice. Atherosclerosis 206, 383-389; doi:10.1016/j.atherosclerosis.2009.02.033

Sena C. M., Seica R. M. (2010): Oxidative stress and endothelial dysfunction: novel therapeutic interventions. In: Advances in Molecular Mechanisms and Pharmacology of Diabetic Complications. (Ed. M. Stefek), Transworld Research Network, 37/661 (2), Fort P.O.Trivandrum-695 023 Kerala, India (In press)

Shi H. P., Wang S. M., Zhang G. X., Zhang Y. J., Barbul A. (2007): Supplemental L-arginine enhances wound healing following trauma/hemorrhagic shock. Wound Repair Regen. 15, 66-70; doi:10.1111/j.1524-475X.2006.00186.x

Shimokawa H., Matoba T. (2004): Hydrogen peroxide as an endothelium-derived hyperpolarizing factor. Pharmacol Res. 49, 543-549; doi:10.1016/j.phrs.2003.10.016

Singer H. A., Peach M. J. (1982): Calcium and endothelial mediated vascular smooth relaxation in rabbit aorta. Hypertension 4 (Suppl. 2), 19-25

Spinetti G., Kraenkel N., Emanueli C., Madeddu P. (2008): Diabetes and vessel wall remodeling: from mechanistic insights to regenerative therapies. Cardiovasc. Res. 78, 265-273; doi: $10.1093 / \mathrm{cvr} / \mathrm{cvn} 039$

Stabile A.M., Moreto V., Antunes-Rodrigues J., Carnio E.C. (2010): Central but not systemic inhibition of inducible nitric oxide synthase modulates oxytocin release during endotoxemic shock. Peptides 31, 706-711; doi:10.1016/ j.peptides.2009.11.004

Stam H., Hulsmann W. C., Jonkid J. F., Van der Kraaij A. M., Koster J. F. (1989): Endothelial lesions, dietary composition and lipid peroxidation. Eicosanoids 2, 1-14

Stanfield C. M., Schilling W. P., Possami L. D., Kunze D. L. (1990): Bradykinin-induced potassium current in culture bovine aortic endothelial cells. J. Neur. Biol. 116, 227-238

Stankevičius E., Kèvelaitis E., Vainorius E., Simonsen U. (2003): Role of nitric oxide and other endothelium-derived factors. Medicina 39, 333-341

Stawicki S. P., Sims C., Sarani B., Grossman M. D., Gracias V. H. (2008): Methylene blue and vasoplegia: who, when, and how? (Mini Rev.), Med. Chem. 8, 472-490

Steinberg D., Parthasarathy S., Carev T. E., Khao J. C., Witztum J. L. (1989): Beyond cholesterol: Modification of low density lipoprotein that increased its atherogenicity. N. Engl. J. Med. 320, 915-924

Stocker R., Keaney J. F. Jr. (2004): Role of oxidative modifications in atherosclerosis. Physiol. Rev. 84, 1381-1478; doi:10.1152/ physrev.00047.2003

Sullivan J. C., Pardieck J. L., Hyndman K. A., Pollock J. S. (2010): Renal NOS activity, expression, and localization in male and female spontaneously hypertensive rats. Am. J. Physiol. Regul. Integr. Comp. Physiol. 298, R61-69; doi:10.1152/ajpregu.00526.2009

Suzuki M., Ohyama Y., Satoh S. (1984): Conversion of angiotensin I to angiotensin II and inactivation of bradykinin in canine peripheral vascular beds. J. Cardiovasc. Pharmacol. 8, 244-250; doi:10.1097/00005344-198403000-00006

Szekanecz Z., Koch A. E. (2008): Vascular involvement in rheumatic diseases: 'vascular rheumatology'. Arthritis Res. Ther. 10, 224-234; doi:10.1186/ar2515

Taddei S., Virdis A., Mattei P., Ghiadoni L., Gennari A., Fasolo C., Sudano I., Salvetti A. (1995): Aging and endothelial function in normotensive subjects and patients with essential hypertension. Circulation 91, 1981-1987

Takei A., Huang Y., Lopes-Virella F. (1998): Intercellular adhesion molecule-1 (ICAM-1) expression induced by oxLDL on human umbilical vein endothelial cells (HUVEC) depends on the stage of LDL oxidation. Diabetes 47, (Suppl.1), A115

Takala H., Saarnio J., Wiik H., Ohtonen P., Soini Y. (2010): HIF-1 alpha and VEGF are associated with disease progression in esophageal carcinoma. J. Surg. Res. (Epub. ahead of print, 2010 Mar 19)

Tesfamariam B. (1994): Free radicals in diabetic endothelial cell dysfunction. Free Rad. Biol. Med. 16, 383-391; doi:10.1016/0891-5849(94)90040-X

Toda N., Herman A. G. (2005): Gastrointestinal function regulation by nitrergic efferent nerves. Pharmacol. Rev. 57, 315-338; doi:10.1124/pr.57.3.4

Toda N., Ayajiki K., Okamura T. (2007): Interaction of endothelial nitric oxide and angiotensin in the circulation. Pharmacol. Rev. 59, 54-87; doi:10.1124/pr.59.1.2

Toda N., Okamura T. (2003): The pharmacology of nitric oxide in the peripheral nervous system of blood vessels. Pharmacol. Rev. 55, 271-324; doi:10.1124/pr.55.2.3 
Tripathi P., Misra M. K. (2009): Therapeutic role of L-arginine on free radical scavenging system in ischemic heart diseases. Indian J. Biochem. Biophys. 6, 498-502

Trouillon R., Cheung C., Patel B. A., O'Hare D. (2010): Electrochemical study of the intracellular transduction of vascular endothelial growth factor induced nitric oxide synthase activity using a multi-channel biocompatible microelectrode array. Biochim. Biophys. Acta 1800, 929-936

Tsai S. K., Lin S. M., Huang C. H., Hung W. C., Chih C. L., Huang S. S. (2004): Effect of desflurane-induced preconditioning following ischemia-reperfusion on nitric oxide release in rabbits. Life Sci. 76, 651-660; doi:10.1016/ j.lfs.2004.05.025

Tsutsui M. (2004): Neuronal nitric oxide synthase as a novel antiatherogenic factor. J. Atheroscler. Thromb. 11, 41-48

Upchurch G. R. Jr., Ford J. W., Weiss S. J., Knipp B. S., Peterson D. A., Thompson R. W., Eagleton M. J., Broady A. J., Proctor M. C., Stanley J. C. (2001): Nitric oxide inhibition increases matrix metalloproteinase- 9 expression by rat aortic smooth muscle cells in vitro. J. Vasc. Surg. 34, 76-83; doi:10.1067/mva.2001.115598

Vanderjagt D. J., Harrison J. M., Ratliff D. M., Hunsaker L. A., Vanderjagt D. L. (2001): Oxidative stress indices in IDDM subjects with and without long-term diabetic complications. Clin. Biochem. 34, 265-270; doi:10.1016/S00099120(01)00204-1

Vane J. R. (1994): The croonian lecture, 1993. The endothelium: maestro of the blood circulation. Biol. Sci. 343, 225-246; doi:10.1098/rstb.1994.0023

Vane J. R., Änggard E. E., Botting R. M. (1990): Regulatory functions of the vascular endothelium. N. Engl. J. Med. 323, 27-36; doi:10.1056/NEJM199007053230106

Van Hinsbergh V. W. M. (1988): Regulation of the synthesis and secretion of plasminogen activators by endothelial cells. Haemostasis 18, 307-327

Vanhoutte P. M. (1988): The endothelium: modulator of vascular smooth muscle tone. N. Engl. J. Med. 319, 512-513; doi:10.1056/NEJM198808253190809

Vanhoutte P. M. (1992): Role of calcium and endothelium in hypertension, cardiovascular disease and subsequent vascular events. J. Cardiovasc. Pharmacol. 19 (Suppl. 3), S6-10

Vanhoutte P. M., Eber B. (1991): Endothelium-derived relaxing and contracting factors. Wien. Klin. Wochenschr. 103, 405-411

Vanhoutte P. M., Hauston D. S. (1985): Platelets, endothelium and vasospasm. Circulation 71, 728-734

Vanhoutte P. M., Lüscher T. F., Graser T. (1991): Endothelium dependent contractions. Blood Vessels 28, 74-83

Vareniuk I., Pacher P., Pavlov I. A., Drel V. R., Obrosova I. G. (2009): Peripheral neuropathy in mice with neuronal nitric oxide synthase gene deficiency. Int. J. Mol. Med. 23, 571-580

Walsh T., Donnelly T., Lyons D. (2009): Impaired endothelial nitric oxide bioavailability: a common link between aging, hypertension, and atherogenesis? J. Am. Geriatr. Soc. 57, 140-145; doi:10.1111/j.1532-5415.2008.02051.x

Wang W., Viappiani S., Sawicka J., Schulz R. (2005): Inhibition of endogenous nitric oxide in the heart enhances matrix metalloproteinase-2 release. Br. J. Pharmacol. 145, 43-49; doi:10.1038/sj.bjp.0706144

Weinberg J. B., Fermor B., Guilak F. (2007): Nitric oxide synthase and cyclooxygenase interactions in cartilage and meniscus: relationships to joint physiology, arthritis, and tissue repair. Subcell. Biochem. 42,31-62; doi:10.1007/1-40205688-5_2

Wilcox J. N., Subramanian R. R., Sundell C. L., Tracey W. R., Pollock J. S., Harrison D. G. Marsden P. A. (1997): Expression of multiple isoforms of nitric oxide synthase in normal and atherosclerotic vessels. Arterioscl. Thromb.Vasc. Biol. 17, 2479-2488

Wittmeyer V., Merrot T., Mazet B. (2010): Tonic inhibition of human small intestinal motility by nitric oxide in children but not in adults. Neurogastroenterol. Motil. (Epub ahead of print, 2010 Jun 11)

Wolf S. P., Jiang Z. Y., Hunt J. V. (1991): Protein glycation and oxidative stress in diabetes melitus and aging. Free Rad. Biol. Med. 10, 339-352; doi:10.1016/0891-5849(91)90040-A

Wong A. Y. K., Klassen G. A. (1992): A model of cytosolic calcium regulation and autocoids production in vascular endothelial cells. Basic. Res. Cardiol. 87, 317-332; doi: $10.1007 / B F 00796518$

Yanagisawa M., Kurikaza H., Kimura S., Tomobe Y., Kobyoshi M., Mitsui Y., Yzaki Y., Goto K., Masaki T. (1988): A novel potent vasoconstrictor peptide produced by vascular endothelial cells. Nature 332, 411-415; doi:10.1038/ $332411 \mathrm{a} 0$

Yang X., Cai B., Sciacca R. R., Cannon P. J. (1994): Inhibition of inducible nitric oxide synthase in macrophages by oxidized low-density lipoproteins. Circulat. Res. 74, 318-328

Young J. C., Schneiderm C., Hartl F. U. (1997): In vitro evidence that hsp90 contains two independent chaperone sites. FEBS Lett. 418, 139-143; doi:10.1016/S00145793(97)01363-X

Zawadski J. V., Chery P. D., Furchgott R. F. (1980): Comparison of endothelium-derived relaxations of rabbit aorta by A23187 and acetylcholine. Pharmacologist 22, 271-275

Zhang Z. Y., Zhang Z., Schluesener H. J. (2010): MS-275, an histone deacetylase inhibitor, reduces the inflammatory reaction in rat experimental autoimmune neuritis. Neuroscience 169, 370-377; doi:10.1016/j.neuroscience.2010.04.074

Zou M. H., Shi C., Cohen R. A. (2002): Oxidation of the zinc-thiolate complex and uncoupling of endothelial nitric oxide synthase by peroxynitrite. J. Clin. Invest. 109, 817-826

Received: May 11, 2010

Final version accepted: September 2, 2010 